
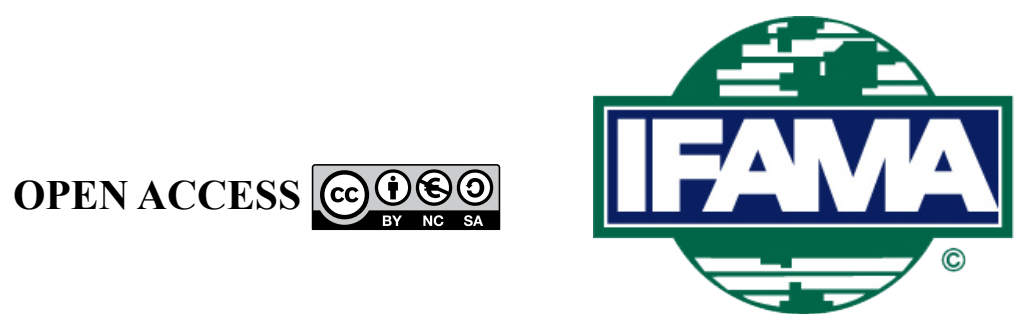

International Food and Agribusiness Management Review

Volume 25, Issue 2, 2022; DOI: 10.22434/IFAMR2020.0206

Received: 13 December 2020 / Accepted: 17 October 2021

\title{
Analysis of competitiveness and economic profit of the confectionary sector in Kazakhstan and its comparison with Czech Republic data \\ RESEARCH ARTICLE
}

\author{
Petr Hájek ${ }^{\oplus a}$, Eva Kan̆kováb and Gulnar Zhunissova ${ }^{\mathrm{c}}$ \\ aAssistant Professor, Unicorn Research Centre, V Kapslovně 2767/2, Prague 13000, Czech Republic \\ ${ }^{b}$ Assistant Professor, Faculty of Business Administration, Prague University of Economics \\ and Business, Nám. W. Churchilla 1938/4, Prague 130 67, Czech Republic \\ 'Senior lecturer, Higher School of Economics and Business, Al Farabi National \\ University, 71 al-Farabi Ave., Almaty 050040, Kazakhstan
}

\begin{abstract}
Measuring competitiveness in post-communist countries in Central Asia is challenging. Many well-known metrics fail to warn bankruptcy risks sufficiently early or at all. This study uses metrics of the Altman z-score, Taffler z-score, IN99, IN01, IN05, and creditworthiness models to assess bankruptcy likelihood and financial performance of local and foreign confectionery companies operating in Kazakhstan during 2007-2018. These companies are Roshen, KDV Yaskino, Konti, Rakhat, and Bayan Sulu. The IN bankruptcy and creditworthiness models are considered in this study because they are found to be more appropriate for post-communist countries. Compared to the well known Altman or Taffler z-score models, they better suit the events and corporate situations peculiar to these countries. The benchmarking INFA system, involving a pyramidal approach developed for Czech companies, provides the economic-value-added (EVA) and component indicators to analyze competitiveness. This study also compares the performance of Kazakhstan companies with Nestlé Czechia and the Czech food industry. The objective is to analyze company competitiveness, bankruptcy probability, and ability to create value. Results show the effectiveness of INFA in analyzing competitiveness and the applicability of IN models to companies from Kazakhstan, Russia, Ukraine, and the Czech Republic.
\end{abstract}

Keywords: bankruptcy, competitiveness, INFA, EVA, ROE JEL code: G32, G33, M48

\footnotetext{
${ }^{\circledR}$ Corresponding author: hajekp@gmail.com
} 


\section{Introduction}

Kazakhstan is famous for its confectionery products of good quality, which are also supplied to neighboring countries. However, during the last decade, the production of confectionery products in Kazakhstan has been affected by many factors. These include the rise of cocoa and sugar prices, depreciation of the local currency (Tenge), and business cycles.

Financial situation of companies operating in Kazakhstan has been analyzed little in the literature. One group of authors used the catastrophe theory for companies selected from various sectors and concluded that 'approach is able to predict on time a developing mismatch in a company's structure and define the moment of entering a critical zone.' (Janshanlo et al., 2016). Another group of authors created a formula for calculating financial recovery efficiency (Alimbekova et al., 2017). However, these papers do not analyze financial performance and accounting indicators of individual companies in Kazakhstan affecting their competitiveness. This study aims to contribute to the existing literature by analyzing companies that cover a significant market share of the confectionery business in Kazakhstan. Benchmarking methods are to be used in order to properly measure a firm's competitiveness by comparing it to its competitors (Nenadál et al., 2011). As a result, it is possible to get a clearer picture of the firm's competitiveness instead of simply comparing it with the recommended coefficient values given in the literature, which do not (and cannot) reflect the specificity of each industry (Nenadál et al., 2011).

Several popular models measuring the likelihood of bankruptcy or solvency conditions in the EU and the US are considered in this study. These are the Altman, Taffler, and IN models. The latter IN models and INFA system providing the economic-value-added (EVA) decomposition are used in the Czech Republic where both are based on data from thousands of Czech companies. This expansive number contrasts with the tens of companies forming the basis of the other models. Each model uses different ratios and variables to show the likelihood of bankruptcy or corporate performance. The authors suggest that using and comparing results of multiple models should allow better understanding of companies' financial performance. The EVA decomposition analysis, provided by the INFA system, informs companies whether they generate economic profit or are profitable purely to cover opportunity costs, or worse. Altogether, these results create an overview of the financial situation of companies competing in the selected market.

This research uses publicly accessible accounting data on companies during 2007-2018 in order to achieve three objectives. The first objective is to evaluate company data using the discriminant analysis models in order to assign a state for each company (e.g. a company with the IN05 value greater than 1.6 in a given year will be assigned the state 'company creates a value'). The results will describe sectoral trends. The second objective is to explain possible causes leading to the assigned states. This explanation is enhanced by discussing individual company developments generating different results among models, by identifying indicators pointing to financial risk periods for analyzed companies, and by arguing that the IN models are more appropriate for companies from other post-communist countries. The third objective is to show that companies from other post-communist countries can effectively use INFA as the pyramidal breakdown of EVA.

In this research the success rate of bankruptcy prediction models is not evaluated because it typically uses data from hundreds of companies as was already done in (Agarwal and Taffler, 2007) or (Machek, 2014). Analyzing the success rate would not lead to reliable conclusions when a small number of companies covering the majority of the confectionery market in Kazakhstan is studied.

Instead, all the models mentioned are used as 'pattern recognition devices' or as a 'measurement device of financial risk' (as the z-score models are called in (Agarwal and Taffler, 2007)). The models use different indicators and thresholds to find periods of financial risk. The comparison is enhanced by discussing the economic situations of analyzed companies and by outlining possible reasons using selected accounting indicators. Such an analysis also benefits from EVA pyramidal breakdown using INFA. EVA decomposition helps understand why a company fell into a risky financial situation and point to changes leading to financial 
stabilization. Combined with bankruptcy models, this research highlights accounting indicators and approaches that show developments in the sector. Apart from sectoral and company financial analysis, this research also offers methods to the government for overseeing and helping companies in periods of financial distress through economic aid programs and to banks for default risk assessment purposes.

Given the first two objectives, the EVA decomposition shows another essential perspective on factors that help a financial manager tackle a financial situation. The INFA method was chosen because it is very fast, focuses on the company's financial performance, analyzes companies of all sizes, and, unlike all the others, is free of charge. The link between bankruptcy or financial risk models and EVA is straightforward: the company that creates economic value moves away from the high financial risk alarm zone(s) and vice versa.

Almost all of benchmarking methods available in the Czech Republic are focused only on small and medium-sized enterprises (Škodáková, 2009). In addition, INFA allows automatic comparison with industry competitors using the industry average and the top in the industry.

The models are applied to local and foreign confectionery companies operating in Kazakhstan during 2007-2018. The companies considered in this study (Roshen, KDV Yaskino, Konti, Rakhat, and Bayan Sulu) operate in different countries. However, all use similar accounting principles based on international financial reporting standards (IFRS). The Kazakhstan based companies have been obliged to follow IFRS since 2007 (KZ Law 234/III, 2007). Thus, 2007, is the first year included in these analyzes. Using the Czech INFA system of utilizing Czech IFRS data also allows for greater relative comparability than using US-based systems or systems developed with data from other than post-communist countries.

Unfortunately, no database of Kazakhstan companies containing accounting indicators is available (unlike e.g. in the Czech Republic). Therefore, an extensive analysis of success rate of prediction models is not currently possible. This study relies on scanned annual reports and excludes companies with erroneous or insufficient data reported.

\section{Methods}

In analyzing financial trends to determine individual companies' financial performance and competitiveness, the availability of indicators determined the need for bankruptcy and creditworthiness models for companies that operated without company market values. Thus, the Altman z-score, Taffler z-score, IN99, IN01, IN05, and creditworthiness models are used as these are suited to the analysis of companies operating in markets where there is difficulty quantifying market value. Apart from the mentioned models, a Czech benchmarking diagnostic system of financial indicators, INFA (MPO, 2018) is used to analyze the economic profit (EVA) creation of companies. Unlike other pyramidal models, the IN models were created and tested on data of industrial enterprises under the conditions of the Czech Republic. The IFRS accounting standards have been used in the Czech Republic since it acceded to the EU in 2004 and for joint-stock companies in Kazakhstan, since 2007. Hence these models are more appropriate for companies of Kazakhstan than models developed using US data, given different market conditions, regulations, and the accounting standards, which may play an important role in determining outcomes.

The peculiarities causing difficulty in analysing companies in Kazakhstan include the sometimes unclear accounting terminology, which results in problematic 'translation' of specific indicators used in various models of other countries. It would be impossible to do such an analysis without consulting local accounting experts knowing the specific terminology for indicators in each Czech, English, Ukrainian, and Kazakh (in Russian language) financial environment. Research based on the plain translation of indicators from local websites would be unusable. For a clear interpretation, a four-language terminology table of indicators is compiled (Appendix A of the Supplementary Material). 
The bankruptcy models belong to a group of indicator systems expected to asses a company's financial situation (Kislingerová and Hnilica, 2008). The term 'financial distress' represents a state in which a company cannot settle debts or the value of its debts exceeds the value of its assets, that is, when a company becomes illiquid or insolvent. The purpose of the bankruptcy models is to detect a threat to the financial strength of the company and predict the likelihood of bankruptcy although the interpretation of results differs among the models. The values of these indicators are essential for banking institutions when deciding to grant or reject credit. Their purpose is to eliminate limitations and potentially identify missing information from the ratios.

Creditworthiness models examine a company's financial strength based on macroeconomic and microeconomic principles and the experience and knowledge of the financial analyst. These models assess the financial strength of one company compared with others, or they use a point system, where the companies are classified according to their financial situation (Grünwald and Holečková, 2007).

\section{The economic environment of Kazakhstan confectionery sector}

The subprime banking crisis in the US started in 2007 and sparked a global recession and crises in various asset markets around the world during the 2-3 years that followed, including in Kazakhstan. The banking sector in Kazakhstan was affected and a credit market freeze resulted in government intervention. During this 'great recession', the price of the main export product of Kazakhstan, crude oil, plummeted. Its price had a significant influence on the exchange rate of Tenge to US\$.

Since then, it has been difficult and expensive for citizens to obtain credit. Banks were highly risk-averse, and bank interest paid by Kazakhstan companies was high, compared with that of EU countries or countries of Eastern Europe. Table 1 shows describes the economic situation. Inflation increased with the depreciation of the Tenge. The Central Bank's decision to increase the target interest rate to contain inflation led to escalating interest expenses of all indebted companies. Consumer expenditures (which include spending on sweets) grew slowly over the last two years similar to gross domestic product (GDP) growth. Possibly, this is due to citizens buying relatively smaller amounts of sweets, and thus, production and sales of the confectionery industry did not rise significantly.

The main import commodity and an unreplaceable production input for the confectionery industry is cocoa. Table 1 displays various indicators of the economy and the sector-related prices of final production, while Figure 1 shows the sector-input prices of imported products. Cocoa prices increased notably during the fall of 2014 and reached multiples of the prices observed during 2007 and 2013. The same chart also shows the effect of a significant increase of the USD to KZT exchange rate (Table 1), which negatively affected the costs of imported commodities for the entire industry. Apart from the expenses mentioned for cocoa, the sector also encountered other import tariffs and price fluctuations, such as for sugar, nuts, and other ingredients not produced in Kazakhstan or the Customs Union countries.

The Eurasian Economic Commission reduced the import duty on cocoa at the start of 2017 from 3-5 to 0\% of the custom's value. The $0 \%$ applies to non-defatted cocoa paste, cocoa butter, and cocoa fat. The new tariff does not affect Rakhat, Bayan Sulu, and Konfety Karagandy, which have their own cocoa bean processing facilities. However, other local companies, such as Hamle (bought in 2017 by Ulker Biskuvi Sanayi for US\$ 3 million) and Almatinskiy Produkt (producing mostly Helva and other cheap products that are less popular), have no equipment for roasting and processing cocoa beans (Euromonitor, 2016).

Sugar takes up to $50 \%$ of the cost of confectionery and any fluctuations in its price significantly affect the cost of final products (Ginsburg, 2017). Ginsburg also notes there is currently zero import tariff on items 'for-processing-imported sugar'.

Konfety Karagandy closed for reconstruction during 2017 and planned to resume operation in 2020 (Bezkorovaynaya, 2018). However, the real estate of the company had been seized by the government, the 
Table 1. Selected indicators of Kazakhstan economy. ${ }^{1}$

\begin{tabular}{|c|c|c|c|c|c|c|c|c|c|c|c|c|c|}
\hline Indicator & 2007 & 2008 & 2009 & 2010 & 2011 & 2012 & 2013 & 2014 & 2015 & 2016 & 2017 & 2018 & 2019 \\
\hline Inflation (\% CPI, annual $)^{2}$ & 10.8 & 17.1 & 7.3 & 7.4 & 8.5 & 5.2 & 5.9 & 6.8 & 6.7 & 14.4 & 7.4 & 6.0 & 5.2 \\
\hline Central bank policy rate ( $\%$ p.a. $)^{3}$ & 11.00 & 10.50 & 7.00 & 7.00 & 7.50 & 5.50 & 5.50 & 5.50 & 16.00 & 12.00 & 10.25 & 10.25 & 9.25 \\
\hline USD to KZT (period average) ${ }^{3}$ & 123 & 120 & 147 & 147 & 147 & 149 & 152 & 179 & 222 & 342 & 326 & 345 & 383 \\
\hline GDP growth (\% p.a. $)^{2}$ & 8.9 & 3.3 & 1.2 & 7.3 & 7.4 & 4.8 & 6.0 & 4.2 & 1.2 & 1.1 & 4.1 & 4.1 & 4.5 \\
\hline $\begin{array}{l}\text { Household final consumption (\% } \\
\text { YoY change, constant KZT) }\end{array}$ & 10.8 & 7.4 & 0.5 & 11.5 & 11.9 & 10.1 & 10.6 & 1.3 & 1.8 & 1.2 & 1.5 & 6.1 & 5.8 \\
\hline $\begin{array}{l}\text { Sugar prices, chocolate, } \\
\text { confectionery products (\% p.a.) }\end{array}$ & 11.6 & 12.6 & 15.2 & 8.6 & 0.6 & 0.7 & 0.2 & 17.0 & 15.8 & 12.6 & 0.6 & 2.2 & 6.2 \\
\hline Sugar prices (\% p.a. $)^{5}$ & 8.6 & 18.2 & 37.2 & 8.8 & -13.6 & -0.2 & -1.9 & 27.0 & 21.4 & 12.5 & -15.4 & 11.3 & -15.0 \\
\hline Chocolate prices $(\% \text { p.a. })^{5}$ & 13.1 & 9.7 & 3.5 & 8.5 & 9.8 & 1.4 & 1.5 & 9.4 & 14.8 & 12.4 & 2.6 & 0.6 & 9.9 \\
\hline Cacao prices $(\% \text { p.a. })^{5}$ & -1.2 & 1.1 & 2.6 & 2.8 & 50.4 & 1.0 & 3.2 & -2.7 & 11.4 & 37.4 & -2.2 & -1.0 & -0.3 \\
\hline
\end{tabular}

${ }^{1} \mathrm{CPI}=$ consumer price index; GDP = gross domestic product; p.a. = per annum; YoY = year-over-year.

2 World Bank (2020).

${ }^{3}$ IMF (2020b).

${ }^{4}$ Authors' calculations based on World Bank (2020) and MNERK (2020).

${ }^{5}$ MNERK (2020).

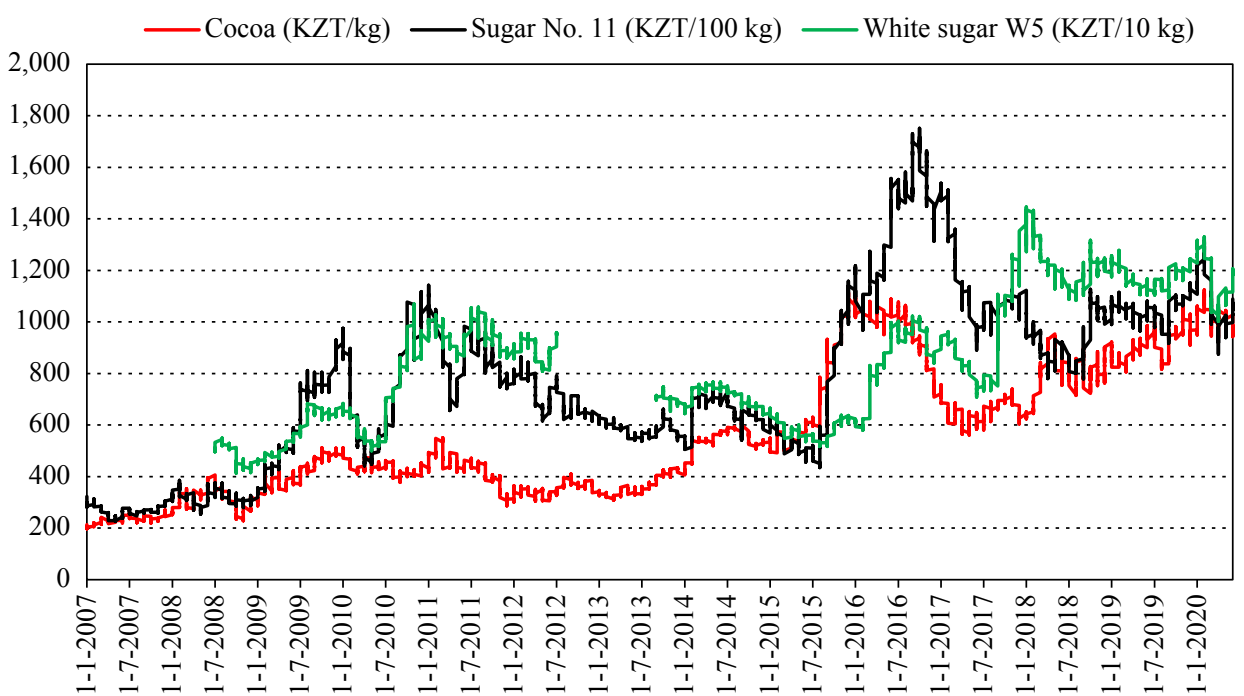

Figure 1. Cocoa and sugar prices on international markets, shown in local currency (KZT) based on the exchange rate (NBK, 2020), cocoa prices (CHRIS-ICE CC1, 2020), sugar no. 11 prices (CHRIS-ICE SB1, 2020), and white sugar W5 (CHRIS-LIFFE W5, 2020).

managers were investigated for criminal charges of legalization of funds acquired by criminal means, and no new investors had been willing to invest in the business (Dergunova, 2019). There have been no further updates about this company as of June 2020 .

\section{Data and confectionery market description}

Financial analysis models are used to assess companies holding a significant portion of the confectionery product market in Kazakhstan. These companies originated from three countries: Kazakhstan with Rakhat joint-stock company (JSC) and Bayan Sulu JSC, the Russian Federation with KDV Yaskino Limited (Ltd.) 
and Konti Ltd., and Ukraine with KCF Roshen JSC. The KCF Roshen company does not represent the entire Roshen holding, which is a Cyprus-located company without publicly available annual reports. Therefore, the study involved the most-referred Ukraine-based company of the Roshen holding, which discloses annual reports with data comparable with other selected companies. The Russian Konti company manages exports to Kazakhstan, Mongolia, Vietnam, and Turkmenistan and imports some goods from Ukraine into the Russian market. Exports to other countries originate in Ukraine. The Ukrainian Konti corporation (Konti JSC, 2020) issued annual reports between 2013 and 2017 using Ukrainian accounting standards and only in 2019 did they use IFRS. In 2019, they only published consolidated financial statements for the Ukrainian part of the business. Due to events in Ukraine in 2014, two of their plants that remained in the territory, and were outside Ukraine's control, were closed. Since then, the Russian part of the Konti company has had no relationship with the accounting of the company's Ukrainian business. Therefore, the study used only the data representing Konti's Russian business, for two reasons. First, no useful data were available for the entire corporation and second, the Russian part of the business produced the goods for the Kazakhstan market.

The study also includes data of Nestlé Česko s.r.o., a Czech subsidiary of Nestlé Suisse S.A, for EVA calculation and comparison purposes. Data were downloaded from publicly available sites for Rakhat (Rakhat, 2020), Bayan Sulu (Bayan Sulu, 2020), KDV Yaskino (KDV - Yaskino reporting, 2020), Roshen (Roshen, 2020), Konti (Konti reporting, 2020), and Nestlé Česko s.r.o. (Nestlé CZ) from annual reports, downloaded from the publicly accessible Ministry of Justice website, justice.cz (Nestlé Česko, 2020). Audited reports of jointstock companies need to be checked for inaccuracies as reported financial statements may include errors causing faulty results of the models used. As a consequence, Konfety Karagandy had to be excluded from the analysis. Nestlé Russia was also excluded because reported data were insufficient for the analysis. The selected period for analysis was 2007-2018 due to the already mentioned introduction of IFRS in Kazakhstan in 2007 and the unavailability of data for most of the analyzed companies preceding 2006. Also, the delay of companies disclosing their accounting data is between one and two years.

The market for sweets is close to its saturation (Rakhat, 2016). The trend in the growth rate of sweets consumption has been decreasing in the past few years. Because of the significant weakening of the national currency and reduction in income affecting subsequently purchasing power of the population, the sales have concentrated in the low-priced market segment. Consumerism switched from more expensive chocolate to more economical confectionery products, such as cookies, waffles, and caramels. The market has a capacity of 227,000 tons with domestic companies producing 183,000 tons, 68,800 tons of which are exported, and another 112,800 tons imported (mostly Russia and Ukraine, as indicated in Table 2a). Newer annual reports from Rakhat or Bayan Sulu do not comment on this issue.

The confectionery market is represented by two segments: sugar and flour confectionery. Rakhat presents, in its annual report, the sugar confectionery market shares, while Bayan Sulu shows all types of confectionery products (Tables $2 \mathrm{a}$ and $2 \mathrm{~b}$ ).

In July 2013, Rakhat was acquired by the Korean conglomerate, Lotte for US\$ 157 million (Nieburg, 2013). The market share of Kazakhstan producers increased during the first 8 months of 2017 by $58.6 \%$ for chocolate and other sweets and by $64.7 \%$ for cookies and other costly products with a long-shelf-life (Tengrinews.kz, 2017). These numbers are closer to those of Rakhat on the one hand, but on the other, are missing the most important end-of-year sales. According to Alikhan Talgatbek, president of the Association of Kazakhstan Confectioners, the Russian export market is the most interesting; China's potential is enormous, but it is highly protectionist in international trade due to high tariffs, for example, $60 \%$ tariff on flour imports. Apart from this, certification and language strongly constrain imports, and taste preferences will differ. At the same time, half of the Kazakh market is comprised of imported products. Talgatbek also points out that this is due to the lower quality of cheaper foreign products, e.g. Russian-made waffles have $70 \%$ fat-based fillings while domestic waffles have 80\% fillings made of walnuts (Kursiv.kz, 2017). Bayan Sulu board chairman, Timur Sadykov, explains problems of the local sector by the low workload of production at $60 \%$, technical lag resulting from insufficient investment in equipment, fierce competition with large foreign holdings, lack 
Table 2a. Kazakhstan market share in terms of sugar confectionery sales (\%).

\begin{tabular}{lrrrrrrrl}
\hline Market share & $\mathbf{2 0 1 2}^{\mathbf{1}}$ & $\mathbf{2 0 1 3}^{\mathbf{1}}$ & $\mathbf{2 0 1 4}^{\mathbf{1}}$ & $\mathbf{2 0 1 5}^{\mathbf{1}}$ & $\mathbf{2 0 1 6}^{\mathbf{1}}$ & $\mathbf{2 0 1 7}^{\mathbf{1}}$ & $\mathbf{2 0 1 7}^{\mathbf{2}}$ & $\mathbf{2 0 1 8}^{\mathbf{3}}$ \\
\hline Rakhat & 38.6 & 40.2 & 41.1 & 40.5 & 38.6 & 45.0 & 42.8 & 61.0 \\
Bayan Sulu & 17.9 & 21.6 & 21.8 & 19.1 & 21.7 & 29.0 & 27.6 & 28.0 \\
Konfety Karagandy & 4.0 & 3.1 & 3.4 & 4.3 & 2.0 & 26.0 & $29.6^{2}$ & $11.0^{3}$ \\
Russian producers & 27.8 & 24.9 & 2.0 & 22.6 & 25.2 & & & \\
Ukrainian producers & 9.2 & 7.6 & 7.3 & 11.8 & 8.0 & & & \\
Other CIS ${ }^{4}$ producers & 0.3 & 0.3 & 0.2 & 0.2 & 0.8 & & & \\
Other foreign producers & 2.0 & 2.2 & 2.3 & 1.5 & 2.7 & & & \\
\hline
\end{tabular}

${ }^{1}$ 2012-2016 (Rakhat, 2016), Annual report of Rakhat (Rakhat, 2017) presents 2017 market share values only for Rakhat, Bayan Sulu, and rest of the market.

22017 annual report of Bayan Sulu (2017) presents 2017 market share values only for Rakhat, Bayan Sulu, and rest of the market.

32018 annual report of Rakhat (2018) indicates data are based on expert opinion while market share values 2018 are presented therein only for Rakhat, Bayan Sulu, and rest of the market.

${ }^{4} \mathrm{CIS}=$ Commonwealth of Independent States.

Table 2b. Kazakhstan market share in terms of sugar and flour confectionery sales (\%). ${ }^{1}$

\begin{tabular}{lcrrrr}
\hline Market share & $\mathbf{2 0 1 3}$ & $\mathbf{2 0 1 4}$ & $\mathbf{2 0 1 5}$ & $\mathbf{2 0 1 6}$ & $\mathbf{2 0 1 7}$ \\
\hline Rakhat & 15 & 20.4 & 17.4 & 22.8 & 19.5 \\
Bayan Sulu & 8.5 & 9.3 & 8.3 & 14.7 & 12.4 \\
Other Kazakhstan producers & 16.5 & 9.6 & 7.6 & 7.7 & 15.7 \\
Foreign producers & 60 & 60.7 & 66.7 & 54.8 & 52.4 \\
\hline
\end{tabular}

${ }^{1}$ Bayan Sulu (2013-2017). Bayan Sulu (2018) provide no relevant information on market shares of sugar and flour confectionery sales.

of access to long-term financing, unavailability of specialists, high cost of imported raw materials, and an unstable exchange rate (Kursiv.kz, 2017).

\section{Results and discussion}

\subsection{Altman z-score}

The Altman z-score belongs to a group of bankruptcy models. Edward Altman, on the grounds of several ratios and statistical analysis, managed to evaluate the bankruptcy likelihood of a company or the probability of decline two years in advance and with up to $70 \%$ success rate five years in advance (Vochozka, 2011). The z-score is known to be about $90 \%$ accurate in forecasting business failure one year into the future and about $80 \%$ accurate in forecasting it two years into the future (CRF, 2017).

Altman constructed this system by using discriminant analysis with five ratios in the equation (Equation 1), making it possible to identify a bankrupting company (Altman, 1968). This model requires companies to be publicly traded. Altman later developed a different version of the z-score model suitable for analyzing non-publicly traded companies (Equation 2) (Credit Guru Inc., 2018). The original z-score employs the market value of debt in Equation 1 whereas a different version of the z-score employs the book value of debt in Equation 2. Due to the unavailability of the 'market value of equity' data, the 'book value of debt' was used in both cases for this study (i.e. Equation 1 uses 'book value of debt' instead of unavailable 'market value of debt'). The models' results would thus differ due to the different coefficients used in the equations.

$$
\begin{aligned}
& Z=1.2 \times X(1)+1.4 \times X(2)+3.3 \times X(3)+0.6 \times X(4)+1.0 \times X(5) \\
& Z=0.717 \times X(1)+0.847 \times X(2)+3.107 \times X(3)+0.42 \times X(4)+0.998 \times X(5)
\end{aligned}
$$


Where:

$\mathrm{X}(1)=$ working capital (current assets - short-term liabilities) / total assets

$\mathrm{X}(2)=$ retained earnings $/$ total assets

$\mathrm{X}(3)=\mathrm{EBIT} /$ total assets

$\mathrm{X}(4)($ Eq. 1$)=$ market value of equity / book value of debt

$\mathrm{X}(4)$ (Eq. 2) = book value of equity / book value of debt

$\mathrm{X}(5)=$ sales / total assets

$\mathrm{Z}>2.99$ (5); $\mathrm{Z}>2.9$ (6) the business is in a good position, financially healthy (green); $1.81<\mathrm{Z}<2.99$ (5); $1.23<Z<2.9$ (6); on alert / gray zone of unmatched results (white); $Z<1.81(5) ; Z<1.81(6)$ bankruptcy has significant probability (red). The higher values of the z-score, the financially healthier the company (Table 3 ).

The Roshen company traded on the Kyiv stock exchange until August 1, 2013 (UX, 2013), resulting in the usage of Equation 2. Roshen also closed and sold the Mariupol factory in 2017. The marginal cost of the transaction reached 65.0 million UAH (about US\$ 2.32 million) while the value of factory assets was 59.5 million UAH (US\$ 2.12 million) at the time (IMM, 2017). The US Dollar (USD) values are based on endof-period USD to UAH data (IMF, 2020a)

Several companies struggled to survive during the Great Recession and the frozen credit market (Table 3). Bayan Sulu struggled through the entire recession because of a significant increase in the volume of receivables. Also, the company received new credit and sold its shares to improve its financial situation. Roshen faced a similar environment in Ukraine and later was and still is affected by the war on Donbas, pushing the company to accumulate long-term credit every year since 2015. The KDV Yaskino company obtained considerable bank credit in 2015, probably to survive the long-term liabilities that skyrocketed in 2014. These measures were likely insufficient as the company's situation, indicated by z-score values (Table 3 ), was continuously deteriorating since 2009 . The Konti situation appears somewhat better. However, the values are near those of the other Russian company, KDV Yaskino, which possibly shared the impact of the embargo on the Russian economy that followed the war on Donbas and corresponded to a 'slow' Russian year-on-year GDP growth and oscillation between -1 and 1\% since 2013 (OECD, 2020).

\subsection{Taffler model (Růčková modification)}

The Taffler model indicates the probability of bankruptcy of a company. Published in 1977 (Atlantis, 2017), the Taffler z-score model has a discriminant function in the form modified by (Růčková, 2011) with four ratios (Equation 3).

$$
\mathrm{TZ}=0.53 \times \mathrm{R} 1+0.13 \times \mathrm{R} 2+0.18 \times \mathrm{R} 3+0.16 \times \mathrm{R} 4
$$

Table 3. Results of the Altman z-score model. ${ }^{1}$

\begin{tabular}{lrrrrrrrrrrrr}
\hline Altman z-score & $\mathbf{2 0 0 7}$ & $\mathbf{2 0 0 8}$ & $\mathbf{2 0 0 9}$ & $\mathbf{2 0 1 0}$ & $\mathbf{2 0 1 1}$ & $\mathbf{2 0 1 2}$ & $\mathbf{2 0 1 3}$ & $\mathbf{2 0 1 4}$ & $\mathbf{2 0 1 5}$ & $\mathbf{2 0 1 6}$ & $\mathbf{2 0 1 7}$ & $\mathbf{2 0 1 8}$ \\
\hline Rakhat & 4.21 & 4.54 & 5.53 & 7.01 & 7.92 & 7.54 & 6.72 & 6.73 & 6.46 & 6.68 & 7.26 & 7.56 \\
Bayan Sulu & 1.27 & 1.53 & 1.07 & 3.22 & 2.83 & 3.27 & 3.18 & 2.90 & 2.30 & 4.91 & 2.83 & 2.30 \\
Roshen & $\mathrm{n} / \mathrm{a}$ & $\mathrm{n} / \mathrm{a}$ & $\mathrm{n} / \mathrm{a}$ & $\mathrm{n} / \mathrm{a}$ & $\mathrm{n} / \mathrm{a}$ & $\mathrm{n} / \mathrm{a}$ & 1.72 & 1.24 & 2.67 & 2.02 & 1.51 & 1.01 \\
KDV-Yashkino & 2.60 & 2.39 & 3.31 & 3.47 & 2.39 & 1.96 & 1.57 & 1.26 & 1.50 & 0.97 & 1.11 & 1.23 \\
Konti & 2.39 & 2.39 & 2.36 & 1.80 & 1.75 & 2.61 & 2.64 & 2.61 & 2.10 & 2.17 & 2.09 & 1.66 \\
\hline
\end{tabular}

${ }^{1}$ Rakhat and Bayan Sulu are publicly traded, therefore Equation 1 was used. In the case of Roshen, KDV Yaskino, and Konti, Equation 2 was used. Colors represent scale levels of the model: green = the business is in a good position, financially healthy; white $=$ on alert / gray zone of unmatched results; red = bankruptcy has significant probability. 
Where:

$\mathrm{TZ}=$ Taffler $\mathrm{Z}$-score

$\mathrm{R} 1$ = earnings before taxes / short-term liabilities

$\mathrm{R} 2=$ current assets / liabilities

$\mathrm{R} 3=$ short-term liabilities / total assets

$\mathrm{R} 4=$ sales / total assets

The following scale levels of the model were distinguished: $\mathrm{TZ}>0.3$, is low probability of bankruptcy of the company (green); $0.2<\mathrm{TZ}<0.3$ gray zone of unmatched results (white); and $\mathrm{TZ}<0.2$, meaning an increased probability of bankruptcy of the company (red) (Table 4).

The original version of the Taffler model uses the share of financial assets, that is, the net of current liabilities to operating costs (instead of sales to total assets) and does not use a gray zone. Enterprises were classified according to the index outcome only on bankruptcy and credibility; zero was the critical value for determining the category. A positive index corresponds with a creditworthy business and vice versa (Vochozka, 2011).

The modification by Růčková uses the same breakdown of enterprises as the established value of the Taffler model. Rather than evaluating enterprises as creditworthy, Růčková refers to the company as having a small probability of bankruptcy and instead of an 'enterprise in bankruptcy', a company with a high probability of bankruptcy. (Růčková, 2011)

Agarwal and Taffler wrote: 'The [Taffler] model is shown to have the clear predictive ability over time period [of 25 years] and dominates more naïve prediction approaches. [This] study also illustrates the economic value to a bank of using such methodologies for default risk assessment purposes' (Agarwal and Taffler, 2007). These authors also noted, 'As such, it is wrong and potentially dangerous to seek to apply the very accessible Altman [z-score US] model in market environments such as the UK. It would be similarly inappropriate to draw any inferences from seeking to apply the listed firm z-score model described in this paper to UK privately-owned firms which have very different financial characteristics.' These authors appear to discourage the use of the model for companies in the UK. Possibly, they would concur the same regarding its use on companies operating in Kazakhstan.

Table 4 shows the Taffler z-scores of the companies, which fluctuated for most companies, apart from Roshen, which appeared to have a high probability of bankruptcy. In 2010, Roshen started to invest in the construction of a new factory in the Lipetsk region of central Russia. The construction finished in 2013 and cost US\$ 250 million (Focus, 2010). In 2013, Roshen, after the approval of the annual accounts 2011-2012, revealed an overstating of net costs and an understating of profit for 2011 and 2012 by its Russian Lipetsk subsidiary. The identified error led to an increase in taxable profits for 2011 and 2012, and an additional payment of 1,307,789.79 RUB (US\$ 22,045) profit tax (Roshen, 2014). The factory in Lipetsk was closed in March 2014 due to problems that emerged during the Russian annexation of Crimea, between February 20 and March 19, 2014 (BBC, 2014). Since 2013, Roshen experienced a fall in short-term liabilities from

Table 4. Results of the Taffler z-score model. ${ }^{1}$

\begin{tabular}{lcccccccccccc}
\hline Taffler & $\mathbf{2 0 0 7}$ & $\mathbf{2 0 0 8}$ & $\mathbf{2 0 0 9}$ & $\mathbf{2 0 1 0}$ & $\mathbf{2 0 1 1}$ & $\mathbf{2 0 1 2}$ & $\mathbf{2 0 1 3}$ & $\mathbf{2 0 1 4}$ & $\mathbf{2 0 1 5}$ & $\mathbf{2 0 1 6}$ & $\mathbf{2 0 1 7}$ & $\mathbf{2 0 1 8}$ \\
\hline Rakhat & 0.91 & 1.00 & 1.32 & 1.98 & 3.06 & 3.05 & 2.92 & 3.26 & 2.21 & 2.47 & 3.18 & 2.13 \\
Bayan Sulu & 0.38 & 0.39 & 0.35 & 0.66 & 0.75 & 0.70 & 0.63 & 0.59 & 0.59 & 0.53 & 0.59 & 0.44 \\
Roshen & $\mathrm{n} / \mathrm{a}$ & $\mathrm{n} / \mathrm{a}$ & $\mathrm{n} / \mathrm{a}$ & $\mathrm{n} / \mathrm{a}$ & $\mathrm{n} / \mathrm{a}$ & $\mathrm{n} / \mathrm{a}$ & 0.20 & 0.21 & 0.26 & 0.18 & 0.16 & 0.18 \\
KDV-Yashkino & 0.79 & 0.81 & 1.27 & 1.25 & 0.56 & 0.46 & 0.35 & 0.40 & 0.33 & 0.25 & 0.23 & 0.23 \\
Konti & 0.62 & 0.60 & 0.60 & 0.47 & 0.47 & 0.67 & 0.70 & 0.70 & 0.58 & 0.53 & 0.69 & 0.42 \\
\hline
\end{tabular}

${ }^{1}$ Colors represent scale levels of the model: green = low probability of bankruptcy of the company; white $=$ gray zone of unmatched results; red = increased probability of bankruptcy of the company. 
US\$ 26.6 million to US\$ 3.7 million in 2015, but since then increased to US\$ 14.9 million in 2018. Total account receivables then increased from 69.8 million UAH (US\$ 8.7 million) in 2013 to 93 million UAH in 2016 (US\$ 3.4 million) to fall to 77.8 million UAH in 2018 (US\$2.8 million). Assets, liabilities, and interest expenses fluctuated, but overall, did not change substantially during the period. Sales plummeted from 495 to 232 million UAH in 2016 (US\$ 20.6 to 8.5 million) but since 2017 sales began to rise and in 2018 reached 373 million UAH (US\$ 13.5 million). Cash increased significantly, from 43,000 and 22,000 UAH (US\$ 5,400 and 1,400, respectively) in 2013 and 2014 to 6.7 and 1.6 million UAH (US\$240,000 and 58,000 , respectively) in 2017 and 2018. In 2013, Roshen experienced the highest debt of the analyzed years when expressed in USD (US\$ 33.1 million; representing 265 million UAH); having that same year the assets of 784 million UAH (US\$ 98 million). The debt then fell to the lowest values in terms of both UAH and USD in 2015 to 127 million UAH (US\$ 5.3 million) rising again since then to 443 million UAH (US\$ 16 million) in 2018 with assets of 992 million UAH (US\$ 35.8 million). Between 2013 and 2018, the owner's equity averaged 526 million, oscillating between 519 million UAH (in 2013) and 549 million UAH (in 2017) with a drop in 2014 to 485 million UAH (US\$ 30.7 million). The net profit was 3.8 million UAH in 2013 (US\$ 475,000), increasing to 34.8 million UAH in 2014 (US\$ 2.21 million), but falling through values of 11.0 million, 4.0 million, to 2.8 million UAH in 2017 (US\$ 459,000, 145,000 and 99,000, respectively) to rise again in 2018 to 11.1 million UAH (US\$ 402,000).

The Roshen company became, in financial terms, a victim of the war in Ukraine and was forced to shut down a newly built Russian factory. The loss of the rich Donbas region caused a significant drop in profit for many Ukrainian companies. The red color for Roshen (Table 4) point to relatively low profit when compared with its short-term liabilities. For KDV Yashino, the z-score values show deterioration since 2009. It remains in the gray zone but with a likelihood of a gradual upward trend to the 0.2 threshold of high bankruptcy. Konti and Bayan Sulu show similar development in the values, both slightly worsening but not as much as KDV Yaskino and certainly not as extreme as Roshen.

\section{IN models - creditworthiness and bankruptcy indexes}

'Creditworthiness' means that the financial performance of the enterprise satisfies the business owner, given the business creates value for its owner. This means that the index can include corporate profitability and risk in its statement (Neumaier and Neumaierová, 2002). The IN models belong to the group of bankruptcy models that were developed for the conditions of the Czech restructuring market during the 1990s (Neumaier and Neumaierová, 2002). The authors using discriminant analysis, ratios, and weighted mean values, created a function to identify the potential bankruptcy of companies. The IN models have gone through several phases of evolution. The first phase was the IN95 index, which focuses on the company from the view of a creditor. It includes 'past-due liabilities', which was omitted in this study because it is not a metric published by companies of Kazakhstan, and considers the business sector of the company. Next, followed the IN99 index, which assesses the company from the perspective of the owner. It is a creditworthiness model where the weights of the individual indicators are set depending on their importance in achieving positive economic profit. The model can thus identify when an enterprise is creating new value for the owner. This model, therefore, indicates the sustainability of a company's competitiveness. The IN99 index may be a suitable indicator of value creation, especially if market prices of the company's shares are unattainable due to a company's inability to report or because of their cost of equity, or both. Often, publicly traded companies do not disclose data, other than a narrow set of accounting information. Also, no investor guidance on markets exists for those with infrequent trades or low liquidity.

The IN01 combines the merits of both the credit and the bankruptcy models and applies to both owners and creditors. Its construction was based on a discriminant analysis of data of 1915 enterprises that were divided into three groups: value-added (583 enterprises), bankruptcy or just before bankruptcy (503 enterprises), and highly representative ( 829 enterprises); the latter group being the sample for extensively defining the model. On the one hand, the model can identify whether the firm creates economic value, and on the other hand, the likelihood of bankruptcy. 
The IN01 connects both of the previous indexes. The last version emerged in 2005 when IN01 was updated into the bankruptcy index IN05 (Neumaierová and Neumaier, 2008).

The IN05 index is an update of the IN01 index according to the Industrial Data Tests of 2004. In addition to assessing whether or not the company will shortly file for the bankruptcy indicated by IN95, the indexes IN01 and IN05 also deal with whether the company creates value for its owners or not. The advantages of the IN05 are that its calculation is simple and financial algorithms are transparent and compatible with publicly-available business-finance data. Also, it can be used for all businesses on the capital market, both publicly and non-publicly traded. It gives clear results and complements parallel indicator systems. However, users must consider that the IN05 index was created and tested using the data of predominantly medium and large industrial enterprises. Thus, for these companies, its capability will work best on annual business performance data. Therefore, it is a performance statement of an enterprise within an annual timeframe, a rough indication characteristic for the whole performance of the business. However, it does not indicate how that performance has been achieved (Neumaierová a Neumaier, 2008).

The bankruptcy prediction success rates of the IN models are $75 \%$ for the IN95 model, $85 \%$ for IN99, $74 \%$ for IN01, and $77 \%$ for IN05. The prediction success rate of IN05 regarding the creation of value is $83 \%$. The larger the company, the higher the success rate. If the resulting value of the IN05 index is lower than the lower bound (0.9), this indicates that the firm is $97 \%$ likely to be heading for bankruptcy and $76 \%$ likely not to create value. The grey zone enterprises will have a $50 \%$ probability of bankruptcy, while $70 \%$ will generate value. Those above the upper limit will have a $92 \%$ probability of non-bankruptcy and a $95 \%$ probability of value creation (Neumaierová and Neumaier, 2005).

The predictive ability of the IN99, IN05, Taffler, Kralicek, and Altman models was tested on a sample of 8924 Czech companies with observations from the period of 2007-2012 concluding 'that the IN05 and IN99 credibility indexes provided the best results, as well as the Altman Z'-score model' (Machek, 2014). Performing similar tests on Kazakhstan companies is currently impossible as there is no such a large database for companies available.

Due to the changing economic environment with the evolution of the Czech Republic during the 1990s from centrally planned to a market-driven economy, the results of running the IN models required consideration of the companies' country and business period. For example, one of the most widely used models (Altman z-score) was constructed on a much smaller sample (compared to IN models) involving US companies doing business under the US accounting standards in 1968, making it a half-century-old model. Thus, the Altman model may not give sufficient weight to the company's liquidity. On the contrary, the model may over-emphasize profitability, a crucial indicator, along with liquidity, which is especially important when assessing long-term financial stability given the conditions of the Czech Republic and other economies of the former Eastern Bloc.

The above model, among other variations, carries a distinctive perceived risk regarding the rate of indebtedness. Where it is common in the US for companies to have up to $80 \%$ foreign capital, in environments analyzed in this study, the results of the US approach would pose problems for both the management and the creditors (in particular) of companies involved. Their expected view of a constructive approach is one adhering to the 'golden rule' of financing when the owner's equity and liabilities are closely balanced. Therefore, the authors considered the IN models as the most suitable for analyzing companies operating in post-communist countries of Eastern Europe or Central Asia.

The IN models can be justifiably used in Kazakhstan because they do not depend on the company's market value, given that in the economic conditions of the Czech Republic and other post-communist countries, such a value is difficult to quantify. This is primarily due to the low explanatory power of capital market pricing data, especially for companies whose securities are traded at exceedingly low liquidity levels. This is 
also the case of Kazakhstan, for which the Czech models are more suitable than the other models that were designed to analyze companies operating in much more liquid, effective and advanced market environments.

\section{IN99 index}

With the success rate of $86.4 \%$, the index establishes the value creation, and with an even higher rate of $98.9 \%$, can identify when there is no value creation (Atlantis, 2017).

$$
\text { IN99 }=-0.017 \times \mathrm{A}+4.573 \times \mathrm{C}+0.481 \times \mathrm{D}+0.015 \times \mathrm{E}
$$

Where:

$\mathrm{A}=$ assets / liabilities

$\mathrm{C}=\mathrm{EBIT} /$ total assets

$\mathrm{D}=$ sales / total assets

$\mathrm{E}=$ current assets / short-term liabilities

The following scale levels of the model were distinguished: IN99 $>2.07$ the company creates a new value for the owner (dark green); $1.42 \leq \mathrm{IN} 99<2.07$ rather it creates value for the owner (green); $1.089 \leq \mathrm{IN} 99<1.42$ it is not possible to determine whether or not a company creates value for the owner (grey); $0.684 \leq \mathrm{IN} 99<1.089$ rather does not create value for the owner (red); IN99<0.684 enterprise does not create value for the owner (dark red) (Table 5).

Table 5 shows that almost all companies experienced challenging times during the decade examined. Due to the decline of oil prices (by about 50\% during the second half of 2014) and the consequences of war in Ukraine (Euromaidan, the annexation of Crimea, Donbas war, and sanctions on Russian economy) the Russian ruble (RUB) depreciated against the US dollar from an exchange rate of 37 for USD to RUB in September 2014 to 68 in February 2015, and 75 in March 2016. As a consequence of the war and economic recession linked to the competitive devaluation of RUB, the Ukrainian Hryvnia (UAH) was devalued $60 \%$ against the US dollar between August 2014 and March 2015. However, the UAH depreciated to the RUB (or RUB appreciated to UAH) during the volatile years of 2014 and 2015 from an exchange rate of about 3.7 for UAH to RUB to about 2.6 for UAH to RUB.

If the Konti results shown in Table 5 represented the entire corporation, the numbers would be astounding, given the environment of recession in Ukraine, frozen credit markets, depreciation of UAH to USD and RUB, and the war in Ukraine. Instead, Table 5 results represent the separate company (rather than a subsidiary) operating from Russia, which possibly helped the company escape the effects of unfavorable UAH exchange rates.

Table 5. Results of IN99. ${ }^{1}$

\begin{tabular}{lcccccccccccc}
\hline IN99 & $\mathbf{2 0 0 7}$ & $\mathbf{2 0 0 8}$ & $\mathbf{2 0 0 9}$ & $\mathbf{2 0 1 0}$ & $\mathbf{2 0 1 1}$ & $\mathbf{2 0 1 2}$ & $\mathbf{2 0 1 3}$ & $\mathbf{2 0 1 4}$ & $\mathbf{2 0 1 5}$ & $\mathbf{2 0 1 6}$ & $\mathbf{2 0 1 7}$ & $\mathbf{2 0 1 8}$ \\
\hline Rakhat & 1.13 & 0.97 & 1.03 & 1.08 & 1.42 & 1.16 & 0.75 & 0.40 & 1.19 & 1.43 & 1.44 & 1.51 \\
Bayan Sulu & 0.66 & 0.96 & 0.68 & 0.73 & 0.65 & 0.62 & 0.62 & 0.68 & 0.79 & 0.89 & 1.14 & 0.78 \\
Roshen & $\mathrm{n} / \mathrm{a}$ & $\mathrm{n} / \mathrm{a}$ & $\mathrm{n} / \mathrm{a}$ & $\mathrm{n} / \mathrm{a}$ & $\mathrm{n} / \mathrm{a}$ & $\mathrm{n} / \mathrm{a}$ & 0.29 & 0.33 & 0.20 & 0.13 & 0.13 & 0.20 \\
KDV-Yashkino & 1.63 & 1.48 & 1.89 & 1.32 & 1.14 & 0.83 & 0.58 & 0.70 & 0.77 & 0.64 & 0.78 & 0.76 \\
Konti & 1.27 & 1.26 & 1.26 & 1.00 & 1.04 & 1.63 & 1.59 & 1.68 & 1.59 & 1.27 & 1.44 & 1.07 \\
\hline
\end{tabular}

${ }^{1}$ Colors represent scale levels of the model: green $=$ rather it creates value for the owner; grey $=$ it is not possible to determine whether or not a company creates value for the owner; red = rather does not create value for the owner; dark red = enterprise does not create value for the owner. 
According to the IN99 results, Konti remained in relatively stronger conditions than the competition. Konti's debt increased from 2.5 billion RUB (US\$ 101 million) in 2007 to 6.6 billion RUB (US\$ 95 million) in 2018. In USD, the debt varied, first falling to US\$ 84 million in 2009, then increasing to US\$ 150 million in 2013, and in 2014 returning to under US\$ 100 million, where it fluctuated between US\$ 91 million and US\$ 104 million until 2018. The earnings after tax (EAT) increased from 187 million RUB (US\$ 7.6 million) to 1.2 billion RUB in both 2014 and 2015 (US\$ 21.7 million in 2014 and US\$ 16.7 million in 2015). Since then, the profit decreased from 519 million RUB in 2016 (US\$ 8.5 million) and 692 million RUB (US\$ 12 million) in 2017 to 239 million RUB (US\$ 3.4 million) in 2018. The revenue in RUB doubled between 2007 and 2013 from 6.45 billion RUB to 13 billion RUB (US\$ 262 million to US\$ 400 million). Since 2014, it gradually decreased to 9.9 billion RUB in 2018 (US\$ 143 million). The development of revenue and profit is weakly linked. The profit margin moved between 2.5 and $2.9 \%$ between 2007 and 2011, through 2012 and 2013, it increased to 6.5 and $7.0 \%$, respectively, and in 2014 and 2015 to $10.2 \%$. Then, it fell to $2.4 \%$ in 2018 (Konti reporting, 2020).

The IN99 results also show that the global recession affected all companies, and only Konti created value for the owner between 2012 and 2015 when the Russian-Ukrainian crisis was at its worst. Before the global recession, KDV Yaskino led, while after 2016, Rakhat out-performed other companies.

\section{IN01 index}

The IN01 merges creditworthiness and bankruptcy models.

$$
\mathrm{IN} 01=0.13 \times \mathrm{A}+0.04 \times \mathrm{B}+3.92 \times \mathrm{C}+0.21 \times \mathrm{D}+0.09 \times \mathrm{E}
$$

Where:

$\mathrm{A}=$ assets / liabilities

$\mathrm{B}=\mathrm{EBIT} /$ interest expenses

$\mathrm{C}=\mathrm{EBIT} /$ total assets

$\mathrm{D}=$ sales / total assets

$\mathrm{E}=$ current assets / short-term liabilities

The following scale levels of the model were distinguished: IN01 $>1.77$ meaning enterprise creates a value (green); $0.75 \leq \mathrm{IN} 01<1.77$ meaning creditworthy business not creating value (grey); IN $01<0.75$ meaning enterprise is on the way to bankruptcy (red) (Table 6).

Similar to IN05, the IN01 incorporates interest expenses. To run the analysis with comparable results, a ceiling of nine was set for the ratio of earnings before interest and tax (EBIT) to interest expenses to avoid higher values (absolute) distorting the z-score result. Neumaier and Neumaierová (2002) noted that where the ratio increases rapidly to infinity, including cases of zero interest expenses or severe problems with credit repayments, nine is the maximum value to use. This ceiling affected the results of IN01 and IN05 for Rakhat,

Table 6. Results of IN01. ${ }^{1}$

\begin{tabular}{lcccccccccccc}
\hline IN01 & $\mathbf{2 0 0 7}$ & $\mathbf{2 0 0 8}$ & $\mathbf{2 0 0 9}$ & $\mathbf{2 0 1 0}$ & $\mathbf{2 0 1 1}$ & $\mathbf{2 0 1 2}$ & $\mathbf{2 0 1 3}$ & $\mathbf{2 0 1 4}$ & $\mathbf{2 0 1 5}$ & $\mathbf{2 0 1 6}$ & $\mathbf{2 0 1 7}$ & $\mathbf{2 0 1 8}$ \\
\hline Rakhat & 1.99 & 2.37 & 2.75 & 3.73 & 4.27 & 4.74 & 5.11 & 6.49 & 3.59 & 3.91 & 4.68 & 3.09 \\
Bayan Sulu & 0.83 & 0.94 & 0.82 & 1.58 & 1.77 & 1.78 & 1.55 & 1.43 & 1.54 & 1.20 & 1.35 & 1.04 \\
Roshen & n/a & n/a & n/a & n/a & n/a & n/a & 0.94 & 0.95 & 1.29 & 1.05 & 0.89 & 0.82 \\
KDV-Yashkino & 2.11 & 2.21 & 2.68 & 2.26 & 1.93 & 1.25 & 1.09 & 0.92 & 0.87 & 0.85 & 0.74 & 0.76 \\
Konti & 1.32 & 1.30 & 1.29 & 1.04 & 1.07 & 1.80 & 1.82 & 1.81 & 1.66 & 1.35 & 1.90 & 1.06 \\
\hline
\end{tabular}

${ }^{1}$ Colors represent scale levels of the model: green = enterprise creates a value; grey = creditworthy business not creating value; red = enterprise is on the way to bankruptcy. 
Roshen, and KDV Yaskino. The IN01 results (Table 6) show a relatively balanced outcome for the whole sector. Rakhat is the only company that created value during the entire study period. Although KDV Yaskino created value between 2007 and 2011, in the remaining years the company failed to do so and fluctuated between not creating value and trending towards bankruptcy from 2012 to 2018 .

\section{IN05 index}

The index formula IN05 according to (Neumaierová and Neumaier, 2005) is:

$$
\mathrm{IN} 05=0.13 \times \mathrm{A}+0.04 \times \mathrm{B}+3.97 \times \mathrm{C}+0.21 \times \mathrm{D}+0.09 \times \mathrm{E}
$$

Where:

$\mathrm{A}=$ assets / liabilities

$\mathrm{B}=\mathrm{EBIT} /$ interest expenses

$\mathrm{C}=\mathrm{EBIT} /$ total assets

$\mathrm{D}=$ sales / total assets

$\mathrm{E}=$ current assets / short-term liabilities

The following scale levels of the model were distinguished: IN05 $>1.6$ meaning the enterprise creates a value (green); $0.9 \leq \mathrm{IN} 05 \leq 1.6$ gray zone of unmatched results (grey); IN $05<0.9$ meaning the enterprise destroys value, threat of bankruptcy (red) (Table 7).

The IN01 and IN05 formulas are very similar but the thresholds are different. Compared to the results of IN01, the IN05 results show more distressing periods for the companies (Table 7). The red color for KDV Yaskino reflects their increasing liabilities. Between 2007 and 2018, their debt increased from 896 million RUB (US\$ 37 million) to 11.11 billion RUB (US\$ 160 million).

The EAT during the whole period was 194 million RUB (US\$ 5.0 million). After 2009, when it reached 393 million RUB (US\$ 13.0 million), the EAT fell to 30 million RUB in 2016 (US\$ 0.5 million). In 2017 and 2018, it was 90 million and 87 million RUB, respectively (US\$ 1.6 million and US\$ 1.3 million, respectively). The financial prediction continued to deteriorate similarly to that shown in the results of IN01 (Table 6) and Taffler z-score (Table 4).

The red color for Bayan Sulu coincides with the economic crisis in Kazakhstan, which appears not to have affected Rakhat (Table 7). Apart from Bayan Sulu, KDV Yashkino and Roshen display the worse annual results, from 2015 onwards. Bayan Sulu increased common capital in 2009 by 16-fold. Their credit also increased significantly in 2009, while cash from operating activities was almost non-existent. The IN05 index appears more sensitive than the IN01, as it points to several threats of bankruptcy. It is possible to see the importance of threshold levels. For example if the one for the 'threat of bankruptcy' increased from 0.9 to 0.96 then it would mark red Bayan Sulu in 2008 when short term receivables more than doubled (increasing

Table 7. Results of IN05. ${ }^{1}$

\begin{tabular}{lcccccccccccc}
\hline IN05 & $\mathbf{2 0 0 7}$ & $\mathbf{2 0 0 8}$ & $\mathbf{2 0 0 9}$ & $\mathbf{2 0 1 0}$ & $\mathbf{2 0 1 1}$ & $\mathbf{2 0 1 2}$ & $\mathbf{2 0 1 3}$ & $\mathbf{2 0 1 4}$ & $\mathbf{2 0 1 5}$ & $\mathbf{2 0 1 6}$ & $\mathbf{2 0 1 7}$ & $\mathbf{2 0 1 8}$ \\
\hline Rakhat & 2.00 & 2.37 & 2.75 & 3.74 & 4.28 & 4.75 & 5.12 & 6.49 & 3.60 & 3.92 & 4.70 & 3.10 \\
Bayan Sulu & 0.84 & 0.94 & 0.82 & 1.59 & 1.78 & 1.78 & 1.55 & 1.43 & 1.55 & 1.21 & 1.35 & 1.04 \\
Roshen & n/a & n/a & n/a & n/a & n/a & n/a & 0.94 & 0.95 & 1.29 & 1.05 & 0.89 & 0.82 \\
KDV-Yashkino & 2.12 & 2.23 & 2.69 & 2.27 & 1.93 & 1.25 & 1.09 & 0.93 & 0.87 & 0.85 & 0.74 & 0.76 \\
Konti & 1.33 & 1.30 & 1.29 & 1.04 & 1.08 & 1.81 & 1.83 & 1.82 & 1.67 & 1.36 & 1.91 & 1.06 \\
\hline
\end{tabular}

${ }^{1}$ Colors represent scale levels of the model: green $=$ the enterprise creates a value; grey $=$ gray zone of unmatched results; red $=$ the enterprise destroys value, threat of bankruptcy. 
from 10 to $15 \%$ of total assets) and current assets were the lowest of analyzed years, and Roshen in 2013 and 2014, when it had minimum cash and high debt levels. Both situations clearly pointing to a high risk periods for both companies.

\section{Creditworthiness index}

The creditworthiness index is mainly used in German-speaking countries (Atlantis, 2017). The credit index is calculated according to the formula:

$$
C I=1.5 \times x 1+0.08 \times x 2+10 \times x 3+5 \times x 4+0.3 \times x 5+0.1 \times x 6
$$

The following ratios are used:

$\mathrm{x} 1=$ cash flow / liabilities

$\mathrm{x} 2=$ total assets / liabilities

$\mathrm{x} 3=$ earnings before taxes / total assets

$\mathrm{x} 4=$ earnings before taxes $/$ sales

$\mathrm{x} 5=$ stocks $/$ sales

$\mathrm{x} 6=$ sales $/$ total assets
Evaluation (colors are shown in Table 8):

$-3<$ CI $<-2=$ extremely bad (dark red)

$-2<\mathrm{CI}<-1=$ very bad (red)

$-1<\mathrm{CI}<0=$ bad (light red)

$0<\mathrm{CI}<1=$ certain problems (dark grey)

$1<\mathrm{CI}<2=$ good (light grey)

$2<\mathrm{CI}<3=$ very good (light green)

$3<\mathrm{CI}=$ extremely good (dark green)

The CI index (Table 8) reflects the results of the IN99 model (Table 5), which showed Roshen worsening in value for the owner since 2014 and thus becoming less creditworthy starting 2015. The IN99 model results also showed KDV Yaskino was in a similar situation, while Bayan Sulu was the third-worst performing company. Konti presents with a 'good' (light grey) to 'very good' (light green) credit rating for most of the period and an extremely good (dark green) in 2017 (Table 8), allowing it an easier access to credit. Rakhat's creditworthiness is shown as 'extremely good' (dark green) from 2007 apart from a dip to 'very good' (light green) in 2008.

\section{Economic value added analysis}

Many authors, such as (Neumaier and Neumaierová, 2002: 205-206) and (Pavelková and Knápková, 2005: 190), recommended EVA as the primary measure of financial perspective in a balanced scorecard (BSC). A balanced scorecard is a system of balanced business performance indicators. It is a management method that links business strategy to the operational activities with an emphasis on measuring performance. The practical application of measuring performance is possible, although not the primary aim of a balanced scorecard or EVA. It is necessary to emphasize that both economic profit and performance are based, in principle, on different assumptions, and one is not conditional on the other.

In 1991, Stewart (1991) published details of a new metric, 'EVA' that, based on their analyzes, drives shareholder value in a better way than other performance measures. As McClure (2019) writes: 'EVA is a

Table 8. Results of creditworthiness index. ${ }^{1}$

\begin{tabular}{lcccccccccccc}
\hline Creditworthiness & $\mathbf{2 0 0 7}$ & $\mathbf{2 0 0 8}$ & $\mathbf{2 0 0 9}$ & $\mathbf{2 0 1 0}$ & $\mathbf{2 0 1 1}$ & $\mathbf{2 0 1 2}$ & $\mathbf{2 0 1 3}$ & $\mathbf{2 0 1 4}$ & $\mathbf{2 0 1 5}$ & $\mathbf{2 0 1 6}$ & $\mathbf{2 0 1 7}$ & $\mathbf{2 0 1 8}$ \\
\hline Rakhat & 3.15 & 2.74 & 3.48 & 4.52 & 3.73 & 7.78 & 10.85 & 11.67 & 8.37 & 7.44 & 11.57 & 5.05 \\
Bayan Sulu & 0.81 & 0.99 & 1.02 & 2.43 & 1.96 & 2.98 & 1.43 & 1.47 & 2.94 & 2.59 & 1.80 & 1.10 \\
Roshen & n/a & n/a & n/a & n/a & n/a & n/a & 0.43 & 1.28 & 0.92 & 0.54 & 0.45 & 0.55 \\
KDV-Yashkino & 3.17 & 3.44 & 4.11 & 2.61 & 2.37 & 0.99 & 0.64 & 1.06 & 0.55 & 0.41 & 0.35 & 0.38 \\
Konti & 1.37 & 1.32 & 1.31 & 1.02 & 1.04 & 2.42 & 2.54 & 2.87 & 2.68 & 1.74 & 4.34 & 1.12 \\
\hline
\end{tabular}

${ }^{1}$ Colors represent scale levels of the model: dark green = extremely good; light green = very good; light grey; good; dark grey = certain problems. 
performance metric that calculates the creation of shareholder value, but it distinguishes itself from traditional financial performance metrics such as net profit and earnings per share (EPS). EVA is the calculation of what profits remain after the costs of a company's capital - both debt and equity - are deducted from operating profit. The idea is simple but rigorous: true profit should account for the cost of capital.'

Bankruptcy models indicate the probability of significant financial difficulties for a company. The link between bankruptcy models and EVA is straightforward: the company that creates economic value is moving away from the bankruptcy alarm zone(s) and vice versa.

Sometimes the company may show a positive EVA, while a bankruptcy model determines it is in the bankruptcy zone. The explanation is that the company has a high return on equity, but at the same time, a high indebtedness, and low liquidity, or low operating performance, or both, that the models evaluate as alarming.

In other words, it is necessary to consider economic profit, which is the difference between revenues and economic costs. The economic concept of costs is the most comprehensive one. In addition to costs in financial terms, economic cost includes opportunity costs, which represent the aggregate value of inserted resources. The goal of EVA is to show ways in which value appreciates or depreciates in time.

Regarding the value of such an indicator were analyzed 161 companies listed on Athens Stock Market, wrote: 'Relative information content tests reveal that stock returns are more closely associated with earnings per share than with EVA (EVA is a registered trademark of Stern Stewart \& CO). However, incremental information content tests suggest that EVA adds considerable explanatory power to earnings per share in explaining stock returns.' That is, it is not an all-important indicator of business but indeed a vital competitiveness indicator that can show a quota of useful information. (Maditinos et al., 2006).

The EVA is determined by three variables: (1) Net Operating Profit After Tax (NOPAT); (2) Capital (C); and (3) Weighted Average Cost of Capital (WACC), in the following equation:

$$
\mathrm{EVA}=\mathrm{NOPAT}-\mathrm{C} \times \mathrm{WACC}
$$

Where: NOPAT is the economic result achieved in respect of the principal business activity of the enterprise; $\mathrm{C}$ is the value of the company's financial resources, which was invested by all investors; and WACC takes into account all the capital providers, reflecting the understanding that capital costs are held not only by borrowers through interest, but also opportunity costs.

Authors Kislingerová (2010) and Mařík and Maříková (2005) understand Capital as that being tied to assets needed to generate an operating profit. In connection with this, however, the question arises as to how these authors consider the part of assets covered by commitments that do not require compensation. Authors Mařik and Maříková (2005: 47) report: 'We exclude the value of assets funded by non-interest-bearing short-term liabilities from operating assets.' Mařík and Mař́ková, therefore, consider not only the assets but also the sources they cover when determining the capital invested. Interestingly, the authors exclude only short-term non-interest-bearing liabilities from assets generating operating profit. However, it is assumed that any noninterest-bearing liabilities could be excluded irrespective of their time character.

Transforming this equation to simplify further calculations allows the following:

$$
\begin{aligned}
& \text { EVA }=\text { NOPAT }- \text { WACC } \times C \\
& \text { EVA }=\text { ROIC } \times C-\text { WACC } \times C \\
& E V A=\text { ROIC } \times C-C\left(r_{d}(1-T) \frac{D}{C}+r_{e} \frac{E}{C}\right)
\end{aligned}
$$




$$
\begin{aligned}
& E V A=\text { ROIC } \times C-r_{d}(1-T) D-r_{e} E \\
& E V A=\left(R O I C-r_{d}(1-T) \frac{D}{C}-r_{e} \frac{E}{C}\right) \times C \\
& E V A=E A T-r_{e} E \\
& E V A=R O E \times E-r_{e} E \\
& E V A=\left(R O E-r_{e}\right) \times E
\end{aligned}
$$

Where:

ROIC $=$ return on invested capital

WACC $=$ weighted average cost of capital

$\mathrm{C}=$ invested capital (of stockholders and creditors)

$\mathrm{D}=$ liabilities

$\mathrm{E}=$ owner's equity

$r_{e}=$ costs of owner's equity

$r_{d}=$ costs of debt

$\mathrm{ROE}=$ return on equity

$\mathrm{E}=$ owner's equity

$\mathrm{D} / \mathrm{C}=$ the share of liabilities on total invested capital $(\mathrm{C}=\mathrm{D}+\mathrm{E})$

$\mathrm{E} / \mathrm{C}=$ share of equity in total invested capital

$\mathrm{T}=$ income tax

While

Asset-based calculation: $\mathrm{C}=$ fixed assets + net working capital and thus net working capital $=$ current assets - short term liabilities

Liabilities-based calculation: $\mathrm{C}=$ liabilities - short term liabilities

The following uses this equation (Equation 9), as all three variables were easy to obtain through the INFA indicator system.

\section{INFA indicator system}

In 2007, the Czech Ministry of Industry and Trade in cooperation with the Prague University of Economics and Business developed and started INFA for all Czech companies. The system uses 18 indicators. The INFA Indicator System (INFA being the registered trademark of Inka and Ivan Neumaier) uses EVA as the core business performance indicator. The INFA is the fundamental instrument of the reference analysis, which is implemented and published annually by the Ministry of Industry and Trade of the Czech Republic. The INFA indicator system is a pyramidal breakdown of EVA. The first version of this system was made public in 2007, and the most recent update took place in 2012. The system was developed using data of Czech industrial companies, collected primarily by the Czech statistical office.

The MPO (Ministry of Industry and Trade of the Czech Republic) materials describe the methodology in detail in (Neumaier, 2012: 14). The INFA is a financial indicator system is similar to Du Pont, ZVEI, and RL indicator systems (Kralicek et al., 2001). With more data about the companies or their branches (production units) in a chosen country, one could also compare the below-presented results with those of linear programming methods (e.g. Data Envelopment Analysis) that inspect technical effectivity of production units (Kršák et al., 2015). However, such data were difficult to obtain, and thus, the approach could only accommodate comparisons of branches within the examined companies. 
Key INFA assumptions:

- The actual or estimated interest rate shall be set at the cost of the liabilities.

- The market value of liabilities is equal to the book value of interest-bearing liabilities.

- Independence of the weighted average cost of capital (WACC) on the capital structure is assumed. Changing the capital structure merely reallocates the total cost of capital between the owners and creditors.

- In the WACC formula, part of the equation (1 - income tax rate) characterizes the taxation used as a share of the net EAT profit on EBIT profit to reflect the actual impact of taxation.

- An EBIT is estimated using an operating profit value.

According to the INFA methodology, a risk estimate combines algorithmizable relationships with probability characteristics (Neumaier, 2012). In principle, the INFA rating model approaches risk assessment as a rating agency. Due to the existence of mathematical and statistical analyzes, based on the available financial data of the company, it is possible to set up a function that leads to results comparable with those of a rating agency. The INFA system works with different risk types. In the online calculation interface, it is possible to add to the risk-free premium, which is determined as the yield of 10-year government bonds, a specific risk premium, or a generated risk margin (and therefore costs of owner's equity, $r_{e}$ ) automatically calculated using the INFA model's internal database. For this study, the INFA model automatically calculated the $r_{e}$. The INFA decomposes the risk premium on: (1) the risk premium for the financial structure; (2) the risk premium for the financial stability; (3) the risk premium for the business risk (as set by the Ministry of Industry and Trade for each sector and year); and (4) the risk premium for the size of the enterprise and the liquidity as:

$$
r_{e}=f(\text { risk }- \text { free rate })+R P(\text { risk margin })
$$

Where:

$\mathrm{RP}=\mathrm{rFINSTRU}+\mathrm{rFINSTAB}+\mathrm{rPOD}+\mathrm{rLA}$

$r F I N S T R U$ is the risk premium for financial structure.

$r F I N S T A B$ is risk premium for financial stability.

$r P O D$ is the risk premium for business risk specified in the MPO table for each sector and years

(oscillating around $3 \%$ ).

$r L A$ is the risk premium for company size and liquidity.

The cost of owner's equity ( $r_{e}$ function) is set to rely only on available data and was appropriate for the chosen industry risk estimation. The level of risk represents the alternative cost of owner's equity, where $r_{e}$ is the return on capital that could be achieved in the case of an investment in an alternative (equally risky) investment opportunity. It is a complex way of calculating opportunity costs.

The return on equity (ROE) calculation according to INFA (Neumaier, 2012):

$$
\mathrm{ROE}=\frac{\mathrm{EAT}}{\mathrm{EBIT}} \times \frac{\frac{\mathrm{EBIT}}{\mathrm{A}}-\left(\operatorname{IR}\left(\frac{\mathrm{MS}}{\mathrm{A}}-\frac{\mathrm{OE}}{\mathrm{A}}\right)\right)}{\frac{\mathrm{OE}}{\mathrm{A}}}
$$

Where ROE is the return on equity, EBIT is earnings before interest and taxes, EAT is earnings after taxes, $\mathrm{A}$ is assets, IR is estimated interest rate, MS is money sources (equity + bonds + bank loans), and OE is owner's equity.

It is important to view the company as a complex mix of various stakeholder interests. Besides the founder, there are shareholders, creditors, employees, suppliers, and customers, who are interested in the profitable existence of the whole organization, each with specific interests. Customers request the lowest prices and highest quality, suppliers the highest prices of delivered goods and services, shareholders the highest return on their investment, employees the highest salaries possible, creditors the highest interest, and the owner the highest return to offset personal risk. The multiple interests need a balanced approach for the long-term profitability of the company, 
Therefore, long-term, one cannot focus only on financial indicators. The key is to find and focus on causes that lead to financial goals. The balanced scorecard method allows this, while INFA does a similar function using different indicators.

Authors Neumaier and Neumaierová (2002: 156) explain INFA and balanced scorecard as follows: '[INFA] represents a skeleton on which all other dimensions can be hung. It is the outcome and concentrated expression of everything that's going on in the company.'

Investors are thus looking for those businesses where EVA is greater than zero. As the shareholder's wealth grows these businesses and the amount of EVA determines how much money will remain for the company to re-invest in further development (e.g. investments into innovations, which are prerequisites of long-term prosperity and competitiveness). Companies where EVA is zero, produce the same amount they re-invest, in terms of opportunity costs. This is not a desirable outcome as the profit covers dividends only and the company lacks funds for investments. In companies where EVA is below zero, deterioration of the value for shareholders takes place, as the company cannot satisfy the requirements of creditors or owners, or both.

Equation 9 shows that to have a positive EVA, ROE needs to be greater than (opportunity costs). It is then that the company creates EVA.

\section{INFA analysis results}

To obtain INFA results, the online system (MPO, 2007) requires 18 indicators; however, not all are mandatory for INFA calculation (the system also calculates other indicators apart from EVA). To determine EVA and values related to the Czech branch of Nestle (a leader of the local confectionery market), the Czech food industry, and the top food-industry company, the study used 13 indicators: sales, interest expenses, earnings before income tax, earnings after taxes, total assets, inventories, account receivables, short-term financial investments (only short-term securities, excludes cash), owner's equity (used in Altman as market value of equity), short-term liabilities, long-term bank and other borrowings, short-term bank and other borrowings, and production-consumption (material costs + energy costs + services).

All accounting values in RUB and KZT were converted into CZK for the EVA calculations using the end-ofyear exchange rate for each year of 2007-2017. As the exchange rate was unavailable for December 31, the nearest available December rate was used. The RUB to KZT exchange rates were obtained from the National Bank of Kazakhstan (NBK, 2018). The CZK to RUB, rates were obtained from the Czech National Bank data (CNB, 2018). The CZK to KZT rate was calculated using these two mentioned exchange rates. The USD values were based on the end-of-year USD to CZK exchange rate obtained from the Czech National Bank (CNB, 2018).

Table 9 shows the Bayan Sulu situation was weak for many years but improved in later years coinciding with the depreciation of the KZT. Rakhat was in a better condition, generating positive EVA since the end of the global recession. Konti's situation improved markedly in 2012, moving from among the worst to that of the best. Since then, it generated best or second-best results among the compared companies and in some years better than Nestlé CZ. Roshen showed slow recovery in terms of these setbacks and experienced positive EVA in 2015, but then a deterioration followed. Comparably, Nestlé CZ fared well during the whole study period, including during the recession of the Czech economy in 2009.

The following presents the ROE for each company, decomposed as asset turnover ratio (sales / assets), return on sales (EAT / sales), financial leverage (assets / owner's equity), return on equity, and equity ratio (owner's equity / assets), which is a proportion of equity used to finance a company's assets. All indicators were calculated using online INFA calculation (MPO, 2017). The ROE decompositions revealed the weaknesses and strengths of each company. The issues arose from lagging behind the competition and needing to improve the profitability of sales, asset turnover, or leverage. 
Table 9. Economic value added calculated using the INFA indicator system (million US\$). ${ }^{1}$

\begin{tabular}{lrrrrrrrrrrrrr}
\hline $\begin{array}{l}\text { Economic-value- } \\
\text { added }\end{array}$ & $\mathbf{2 0 0 7}$ & $\mathbf{2 0 0 8}$ & $\mathbf{2 0 0 9}$ & $\mathbf{2 0 1 0}$ & $\mathbf{2 0 1 1}$ & $\mathbf{2 0 1 2}$ & $\mathbf{2 0 1 3}$ & $\mathbf{2 0 1 4}$ & $\mathbf{2 0 1 5}$ & $\mathbf{2 0 1 6}$ & $\mathbf{2 0 1 7}$ & $\mathbf{2 0 1 8}$ \\
\hline Rakhat & & & & & & & & & & & & \\
Bayan Sulu & -0.31 & 4.39 & -1.49 & 0.93 & 3.76 & 7.49 & 3.06 & 3.17 & 6.90 & 14.10 & 15.76 & 14.98 \\
Roshen & -2.33 & -0.25 & -4.99 & -5.28 & -1.25 & -0.15 & -4.45 & -3.45 & 0.73 & 3.01 & 4.13 & 0.27 \\
KDV-Yashkino & $\mathrm{n} / \mathrm{a}$ & $\mathrm{n} / \mathrm{a}$ & $\mathrm{n} / \mathrm{a}$ & $\mathrm{n} / \mathrm{a}$ & $\mathrm{n} / \mathrm{a}$ & $\mathrm{n} / \mathrm{a}$ & -10.25 & -4.01 & 3.29 & -3.83 & -2.47 & -3.27 \\
Konti & 4.28 & 2.58 & 4.32 & 3.08 & -2.77 & -10.47 & -4.89 & 1.22 & -4.90 & -6.94 & -5.87 & -3.79 \\
Nestlé Czech Republic & -5.19 & -5.29 & -4.25 & -4.99 & -5.50 & 12.85 & 10.36 & 12.98 & 9.56 & 8.18 & 9.43 & -0.35 \\
\hline
\end{tabular}

${ }^{1}$ Shading indicates a rating of best relative values (green) to worst (red).

\subsection{Roshen}

Table 10 shows Roshen with a ROS (return on sales) that was in double digits in 2014 but quite low in other years. Coinciding with problematic access to credit and a dramatic increase in self-financing, the company's ER reached $81 \%$ in 2015 and $75 \%$ in 2016, while not falling below $54 \%$ overall. This suggests the bankruptcy and creditworthiness models can predict a worsening of access to credit. However, Roshen's owner is a former Ukrainian president, and therefore, the company's credit access may or may not have been blocked. The ATR was also falling with relatively low sales to high assets. The year 2018 brought a small change with ATR slightly better than in the previous two years and ROS especially at about triple the previous year's value. Table 10 and Appendix B of the Supplementary Material show more details.

\subsection{Rakhat}

For Rakhat, a positive EVA prevailed across the study period except for 2007 and 2009 (Table 11). The cause of the poor rating for EVA in 2009 was a 51.13\% year-on-year (YoY) decline in ROE due to a 55.56\% decrease in ROS. Based on accounting data, it can be assumed that the higher costs were caused, at least

Table 10. Results of INFA analysis for Roshen return on equity decomposition. ${ }^{1}$

\begin{tabular}{lcccccc}
\hline Roshen & $\mathbf{2 0 1 3}$ & $\mathbf{2 0 1 4}$ & $\mathbf{2 0 1 5}$ & $\mathbf{2 0 1 6}$ & $\mathbf{2 0 1 7}$ & $\mathbf{2 0 1 8}$ \\
\hline Return on sales & $0.8 \%$ & $11.8 \%$ & $4.4 \%$ & $1.7 \%$ & $1.1 \%$ & $3.0 \%$ \\
Asset turnover ratio & 0.63 & 0.36 & 0.38 & 0.33 & 0.33 & 0.38 \\
Financial leverage & 1.51 & 1.69 & 1.24 & 1.33 & 1.45 & 1.84 \\
Return on equity & $0.7 \%$ & $7.2 \%$ & $2.1 \%$ & $0.7 \%$ & $0.5 \%$ & $2.1 \%$ \\
Equity ratio & $66.2 \%$ & $59.3 \%$ & $80.8 \%$ & $75.2 \%$ & $69.2 \%$ & $54.3 \%$ \\
\hline
\end{tabular}

${ }^{1}$ Indicator values' background is scaled from best (green) to worst (red).

Table 11. Results of INFA analysis for Rakhat return on equity decomposition. ${ }^{1,2}$

\begin{tabular}{lcccccccccccc}
\hline Rakhat & $\mathbf{2 0 0 7}$ & $\mathbf{2 0 0 8}$ & $\mathbf{2 0 0 9}$ & $\mathbf{2 0 1 0}$ & $\mathbf{2 0 1 1}$ & $\mathbf{2 0 1 2}$ & $\mathbf{2 0 1 3}$ & $\mathbf{2 0 1 4}$ & $\mathbf{2 0 1 5}$ & $\mathbf{2 0 1 6}$ & $\mathbf{2 0 1 7}$ & $\mathbf{2 0 1 8}$ \\
\hline ROS & $6.0 \%$ & $8.7 \%$ & $4.2 \%$ & $4.6 \%$ & $5.1 \%$ & $6.7 \%$ & $4.3 \%$ & $5.3 \%$ & $9.9 \%$ & $9.9 \%$ & $11.7 \%$ & $12.3 \%$ \\
ATR & 1.31 & 1.42 & 1.52 & 1.60 & 1.77 & 1.64 & 1.57 & 1.41 & 1.25 & 1.51 & 1.43 & 1.28 \\
FL & 1.34 & 1.25 & 1.18 & 1.17 & 1.15 & 1.12 & 1.14 & 1.33 & 1.19 & 1.18 & 1.17 & 1.15 \\
ROE & $10.5 \%$ & $15.5 \%$ & $7.5 \%$ & $8.6 \%$ & $10.5 \%$ & $12.3 \%$ & $7.7 \%$ & $10.0 \%$ & $14.7 \%$ & $17.6 \%$ & $19.5 \%$ & $18.2 \%$ \\
ER & $74.5 \%$ & $80.1 \%$ & $84.9 \%$ & $85.3 \%$ & $86.7 \%$ & $89.4 \%$ & $87.6 \%$ & $75.1 \%$ & $84.2 \%$ & $84.5 \%$ & $85.8 \%$ & $86.7 \%$ \\
\hline
\end{tabular}

\footnotetext{
${ }^{1}$ Indicator values' background is scaled from best (green) to worst (red).
}

${ }^{2} \mathrm{ATR}=$ asset turnover ratio; $\mathrm{ER}=$ equity ratio; $\mathrm{FL}=$ financial leverage; $\mathrm{ROE}=$ return on equity; $\mathrm{ROS}=$ return on sales. 
partially, to an increase in inventories. The dramatic income fell in 2009 coincided with the financial crisis (while sales still increased). Although the cocoa prices were falling between June and November 2008, they rose markedly during 2009, increasing the costs. Since 2010, the EVA has remained positive and, apart from 2013, trended upwards. The EVA decomposition (Table 9) revealed falls in EVA in 2013 and 2014 and these coincided with a decline in ROS, and a decrease in asset turnover (Table 11 and Appendix B of the Supplementary Material). In other words, the company had additional assets corresponding to a given volume of sales that were probably linked to higher costs.

\subsection{Bayan Sulu}

Bayan Sulu was one of the weakest and potentially least competitive among the companies surveyed, evidenced by its ability to generate economic profit. A positive EVA was first reached in 2015 (Table 9). In addition to the low return on equity, the company had a high alternative cost of equity, especially until 2010. In the following years, the company's financial strength improved and the cost of equity dropped, but there was also a fall in ROE. The year 2015 was promising for the company. The ROE grew almost four times for YoY, and equity costs dropped by about 37\%. However, in 2016, costs rose again to slightly above the 2014 level, and ROS fell by 46\%. In 2017 a slightly better ROS, ROE, and leverage are seen (Table 12 and Appendix B of the Supplementary Material).

\subsection{KDV Yaskino}

The company generated a positive EVA from 2007 to 2010 (Table 9). In 2011, however, the EVA dropped by US\$ 5.85 million, and in 2012 it plummeted to US\$ -10.47 million. In 2014, the company managed to return to a positive EVA, but again in 2015, the EVA was negative (falling by US\$ 6.12 million). The negative trend of EVA below US\$ -6 million continued throughout 2016 and 2017.

To identify the main problem areas associated with the highest EVA drop (US\$ -10.47 million), the 2012 results were investigated in greater detail. The EVA pyramidal breakdown for 2012 indicated, in addition to an increase in equity costs, that the extremely low level of return on equity $(5.65 \%)$ was the main cause of this deep fall in EVA. At the cost of equity $\left(r_{e}\right)$ of $25.75 \%$, arose a negative spread of $-20.11 \%$.

The highest level of ROE, which shows the real potential of the company, was achieved in 2007 at $31.13 \%$ (Table 13). This ROE would be sufficient for generating a positive EVA at the high costs recorded in 2012.

The extremely low ROS that decreased in 2012 compared to 2007 by $83.34 \%$, especially explains the company's problems. Comparing the growth rate of sales with that of costs showed sales grew by $40.32 \%$, whereas costs grew by $57.8 \%$. The growth rate of costs thus exceeded the growth rate of sales by $17.48 \%$. As an example, the depreciation of fixed assets in 2012 was more than two times higher than in 2007.

Table 12. Results of INFA analysis for Bayan Sulu return on equity decomposition. ${ }^{1,2}$

\begin{tabular}{lcccccccccccc}
\hline B. Sulu & $\mathbf{2 0 0 7}$ & $\mathbf{2 0 0 8}$ & $\mathbf{2 0 0 9}$ & $\mathbf{2 0 1 0}$ & $\mathbf{2 0 1 1}$ & $\mathbf{2 0 1 2}$ & $\mathbf{2 0 1 3}$ & $\mathbf{2 0 1 4}$ & $\mathbf{2 0 1 5}$ & $\mathbf{2 0 1 6}$ & $\mathbf{2 0 1 7}$ & $\mathbf{2 0 1 8}$ \\
\hline ROS & $2.0 \%$ & $4.5 \%$ & $2.9 \%$ & $3.0 \%$ & $3.9 \%$ & $4.4 \%$ & $2.3 \%$ & $2.4 \%$ & $9.1 \%$ & $4.9 \%$ & $6.1 \%$ & $4.0 \%$ \\
ATR & 0.87 & 1.21 & 0.88 & 1.08 & 0.90 & 0.87 & 0.98 & 1.01 & 0.75 & 1.03 & 1.23 & 0.91 \\
FL & 5.45 & 5.32 & 3.78 & 1.34 & 1.38 & 1.28 & 1.34 & 1.44 & 1.73 & 1.87 & 1.66 & 1.90 \\
ROE & $9.4 \%$ & $28.8 \%$ & $9.7 \%$ & $4.3 \%$ & $4.9 \%$ & $4.9 \%$ & $3.1 \%$ & $3.5 \%$ & $11.9 \%$ & $9.5 \%$ & $12.4 \%$ & $6.9 \%$ \\
ER & $18.3 \%$ & $18.8 \%$ & $26.5 \%$ & $74.8 \%$ & $72.4 \%$ & $77.9 \%$ & $74.8 \%$ & $69.3 \%$ & $57.9 \%$ & $53.3 \%$ & $60.2 \%$ & $52.7 \%$ \\
\hline
\end{tabular}

${ }^{1}$ Indicator values' background is scaled from best (green) to worst (red).

${ }^{2} \mathrm{ATR}=$ asset turnover ratio; $\mathrm{ER}=$ equity ratio; $\mathrm{FL}=$ financial leverage; $\mathrm{ROE}=$ return on equity; $\mathrm{ROS}=$ return on sales. 
Inventories increased in 2012 compared to 2007 by $203.50 \%$. A comparison of inventories with the growth rate of sales, which was $40.32 \%$, indicates the company had a major problem with inventory management (Table 13 and Appendix B of the Supplementary Material).

\subsection{Konti}

From 2008 to 2011, the Konti company developed unfavorably. The EVA oscillated in the negative territory between US\$ -4.25 and -5.5 million (Table 9).

A better turnover was recorded in 2012 when the company's EVA shifted to positive values, starting at US\$ 12.85 million, and remained there through 2017, oscillating between relatively high values of US\$ 8.18 million and US\$ 12.98 million. This result among the analyzed companies competing in the Kazakhstan market was surpassed only by Roshen in 2016. In 2012, the YoY performance changed by an incredible US\$ 18.35 million. In 2018, the EVA fell considerably from US\$ 9.43 million to -0.35 million.

A positive change occurred due to an increase in ROE when the YoY performance increase was 104.5\% (in 2012). Improvements occurred both in the growth of return on sales (by 150\%) and in the growth of assets turnover (by $18.92 \%$ ). Both factors were offset by the $-30.1 \%$ decrease in financial leverage.

Comparing the growth rate of revenue with that of costs revealed that the growth rate of sales was ahead of the growth rate of costs by about $7.36 \%$ (in 2012). The higher efficiency of asset utilization is directly related to an inventories-to-sales ratio decrease of $-18.72 \%$ (Table 14 and Appendix B of the Supplementary Material).

Table 13. Results of INFA analysis for KDV Yaskino return on equity decomposition. ${ }^{1,2}$

\begin{tabular}{lcccccccccccc}
\hline KDV Y. & $\mathbf{2 0 0 7}$ & $\mathbf{2 0 0 8}$ & $\mathbf{2 0 0 9}$ & $\mathbf{2 0 1 0}$ & $\mathbf{2 0 1 1}$ & $\mathbf{2 0 1 2}$ & $\mathbf{2 0 1 3}$ & $\mathbf{2 0 1 4}$ & $\mathbf{2 0 1 5}$ & $\mathbf{2 0 1 6}$ & $\mathbf{2 0 1 7}$ & $\mathbf{2 0 1 8}$ \\
\hline ROS & $12.2 \%$ & $12.9 \%$ & $14.9 \%$ & $7.8 \%$ & $8.2 \%$ & $2.2 \%$ & $1.8 \%$ & $5.2 \%$ & $1.6 \%$ & $0.3 \%$ & $0.9 \%$ & $0.7 \%$ \\
ATR & 1.32 & 1.14 & 1.36 & 1.42 & 1.21 & 1.38 & 1.02 & 0.75 & 0.96 & 0.81 & 0.87 & 0.93 \\
FL & 1.93 & 1.90 & 1.52 & 1.36 & 1.53 & 1.88 & 2.71 & 4.60 & 4.80 & 7.68 & 6.84 & 9.52 \\
ROE & $31.1 \%$ & $27.9 \%$ & $30.8 \%$ & $15.1 \%$ & $15.1 \%$ & $5.6 \%$ & $5.1 \%$ & $17.9 \%$ & $7.6 \%$ & $1.8 \%$ & $5.3 \%$ & $6.7 \%$ \\
ER & $51.7 \%$ & $52.5 \%$ & $65.6 \%$ & $73.4 \%$ & $65.5 \%$ & $53.2 \%$ & $36.9 \%$ & $21.7 \%$ & $20.8 \%$ & $13.0 \%$ & $14.6 \%$ & $10.5 \%$ \\
\hline
\end{tabular}

${ }^{1}$ Indicator values' background is scaled from best (green) to worst (red).

${ }^{2} \mathrm{ATR}=$ asset turnover ratio; $\mathrm{ER}=$ equity ratio; $\mathrm{FL}=$ financial leverage; $\mathrm{ROE}=$ return on equity; $\mathrm{ROS}=$ return on sales.

Table 14. Results of INFA analysis for Konti return on equity decomposition. ${ }^{1,2}$

\begin{tabular}{lcccccccccccc}
\hline Konti & $\mathbf{2 0 0 7}$ & $\mathbf{2 0 0 8}$ & $\mathbf{2 0 0 9}$ & $\mathbf{2 0 1 0}$ & $\mathbf{2 0 1 1}$ & $\mathbf{2 0 1 2}$ & $\mathbf{2 0 1 3}$ & $\mathbf{2 0 1 4}$ & $\mathbf{2 0 1 5}$ & $\mathbf{2 0 1 6}$ & $\mathbf{2 0 1 7}$ & $\mathbf{2 0 1 8}$ \\
\hline ROS & $2.9 \%$ & $2.9 \%$ & $2.9 \%$ & $2.7 \%$ & $2.6 \%$ & $6.5 \%$ & $7.0 \%$ & $10.2 \%$ & $10.2 \%$ & $4.4 \%$ & $6.6 \%$ & $2.4 \%$ \\
ATR & 1.80 & 1.82 & 1.83 & 1.41 & 1.48 & 1.76 & 1.66 & 1.42 & 1.26 & 1.36 & 1.44 & 1.26 \\
FL & 3.22 & 3.04 & 3.33 & 4.22 & 4.05 & 2.83 & 2.67 & 2.69 & 3.43 & 3.75 & 5.45 & 6.09 \\
ROE & $16.8 \%$ & $15.9 \%$ & $17.8 \%$ & $16.1 \%$ & $15.4 \%$ & $32.5 \%$ & $31.2 \%$ & $38.9 \%$ & $44.5 \%$ & $22.5 \%$ & $52.1 \%$ & $18.4 \%$ \\
ER & $31.1 \%$ & $32.8 \%$ & $30.0 \%$ & $23.7 \%$ & $24.7 \%$ & $35.3 \%$ & $37.4 \%$ & $37.1 \%$ & $29.1 \%$ & $26.7 \%$ & $18.4 \%$ & $16.4 \%$ \\
\hline
\end{tabular}

${ }^{1}$ Indicator values' background is scaled from best (green) to worst (red).

${ }^{2} \mathrm{ATR}=$ asset turnover ratio; $\mathrm{ER}=$ equity ratio; $\mathrm{FL}=$ financial leverage; $\mathrm{ROE}=$ return on equity; $\mathrm{ROS}=$ return on sales. 


\subsection{Nestlé CZ}

Nestlé CZ optimizes cash flow highly effectively under the auspices of the whole multinational company. The company uses the services of NTC-Europe S.A. based on zero balances due to a cash-pooling structure. Loans are then drawn from related parties (e.g. Nestlé CZ draws a loan from Nestlé Finance International Ltd.). Table 15 shows the ROE level of Nestlé CZ that suggests within the food sector, the sweets segment is especially lucrative.

The average values for the 2007-2018 period (Table 15), show Nestlé CZ ROE (Table 16) was more than three times the value of the food industry in the Czech Republic (CZ) and 55\% higher than the best-performing companies in the $\mathrm{CZ}$ industry. The best Czech companies in the industry were based on averages of companies that created a positive EVA. The breakdown of ROE for the average values shows that, for Nestle CZ, the indicators of inventory turnover and financial leverage were favorable. Roshen was the worst performer, while Rakhat the best of the Kazakhstan companies in terms of ROE, ROS, and ATR, and Konti the best of the non-Kazakhstan companies competing in the Kazakhstan market. The Czech food industry and Roshen both had the lowest average ROS for the period. The financial leverage of Nestlé CZ was almost double that of the Czech food industry (Table 17) and more than double that of the best Czech companies in the industry (Table 18).

Comparison results of return on sales, asset turnover ratio, and financial leverage across analyzed companies are provided in Appendix C of the Supplementary Material.

Table 15. Averaged indicator values of companies during the analyzed period for Roshen (2013-2018) and other companies (2007-2018). ${ }^{1}$

\begin{tabular}{lrccc}
\hline Indicators & $\mathbf{R O E}^{\mathbf{2}}$ & $\mathbf{R O S}^{\mathbf{2}}$ & $\mathbf{A T R}^{\mathbf{2}}$ & $\mathbf{F L}^{\mathbf{2}}$ \\
\hline Rakhat & $12.72 \%$ & $7.4 \%$ & 1.48 & 1.20 \\
Bayan Sulu & $9.10 \%$ & $4.1 \%$ & 0.98 & 2.37 \\
Roshen & $2.22 \%$ & $3.8 \%$ & 0.40 & 1.51 \\
Yaskino - KDV & $14.17 \%$ & $5.7 \%$ & 1.10 & 3.86 \\
Konti & $26.86 \%$ & $5.1 \%$ & 1.54 & 3.73 \\
Nestlé CZ & $38.65 \%$ & $7.9 \%$ & 1.24 & 4.08 \\
Food industry CZ & $11.38 \%$ & $3.8 \%$ & 1.54 & 1.98 \\
Best in the CZ industry & $24.81 \%$ & $7.7 \%$ & 1.74 & 1.82 \\
\hline
\end{tabular}

${ }^{1}$ Indicator values' background is scaled from best (green) to worst (red).

${ }^{2} \mathrm{ATR}=$ asset turnover ratio; $\mathrm{CZ}=\mathrm{Czech}$ Republic; $\mathrm{FL}=$ financial leverage; $\mathrm{ROE}=$ return on equity; $\mathrm{ROS}=$ return on sales.

Table 16. Results of INFA analysis for Nestlé CZ return on equity decomposition. ${ }^{1,2}$

\begin{tabular}{lcccccccccccc}
\hline & $\mathbf{2 0 0 7}$ & $\mathbf{2 0 0 8}$ & $\mathbf{2 0 0 9}$ & $\mathbf{2 0 1 0}$ & $\mathbf{2 0 1 1}$ & $\mathbf{2 0 1 2}$ & $\mathbf{2 0 1 3}$ & $\mathbf{2 0 1 4}$ & $\mathbf{2 0 1 5}$ & $\mathbf{2 0 1 6}$ & $\mathbf{2 0 1 7}$ & $\mathbf{2 0 1 8}$ \\
\hline ROS & $7.3 \%$ & $8.0 \%$ & $9.2 \%$ & $8.1 \%$ & $7.7 \%$ & $8.6 \%$ & $5.7 \%$ & $4.6 \%$ & $6.6 \%$ & $7.7 \%$ & $10.4 \%$ & $11.3 \%$ \\
ATR & 1.2 & 1.2 & 1.2 & 1.2 & 1.2 & 1.1 & 1.4 & 1.4 & 1.2 & 1.2 & 1.5 & 1.0 \\
FL & 2.6 & 2.8 & 2.5 & 2.6 & 2.8 & 2.8 & 5.4 & 6.2 & 6.0 & 5.9 & 3.8 & 5.6 \\
ROE & $23.7 \%$ & $26.7 \%$ & $27.2 \%$ & $25.4 \%$ & $26.6 \%$ & $26.4 \%$ & $41.9 \%$ & $40.0 \%$ & $47.3 \%$ & $52.6 \%$ & $59.6 \%$ & $66.4 \%$ \\
ER & $37.9 \%$ & $35.9 \%$ & $39.9 \%$ & $39.0 \%$ & $35.2 \%$ & $36.1 \%$ & $18.5 \%$ & $16.1 \%$ & $16.6 \%$ & $17.1 \%$ & $26.2 \%$ & $17.9 \%$ \\
\hline
\end{tabular}

${ }^{1}$ Indicator values' background is scaled from best (green) to worst (red).

${ }^{2} \mathrm{ATR}=$ asset turnover ratio; $\mathrm{CZ}=\mathrm{Czech}$ Republic; $\mathrm{ER}=$ equity ratio; $\mathrm{FL}=$ financial leverage; $\mathrm{ROE}=$ return on equity; $\mathrm{ROS}=$ return on sales. 
Table 17. Results of INFA analysis for food industry CZ return on equity decomposition. ${ }^{1,2}$

\begin{tabular}{lcccccccccccc}
\hline & $\mathbf{2 0 0 7}$ & $\mathbf{2 0 0 8}$ & $\mathbf{2 0 0 9}$ & $\mathbf{2 0 1 0}$ & $\mathbf{2 0 1 1}$ & $\mathbf{2 0 1 2}$ & $\mathbf{2 0 1 3}$ & $\mathbf{2 0 1 4}$ & $\mathbf{2 0 1 5}$ & $\mathbf{2 0 1 6}$ & $\mathbf{2 0 1 7}$ & $\mathbf{2 0 1 8}$ \\
\hline ROS & $1.7 \%$ & $3.0 \%$ & $4.1 \%$ & $3.8 \%$ & $5.0 \%$ & $3.9 \%$ & $3.1 \%$ & $3.9 \%$ & $3.4 \%$ & $4.2 \%$ & $4.6 \%$ & $4.9 \%$ \\
ATR & 1.68 & 1.71 & 1.67 & 1.48 & 1.52 & 1.64 & 1.68 & 1.54 & 1.57 & 1.42 & 1.34 & 1.27 \\
FL & 2.36 & 2.30 & 2.04 & 2.08 & 2.04 & 1.99 & 1.91 & 1.80 & 1.86 & 1.77 & 1.83 & 1.81 \\
ROE & $6.9 \%$ & $11.6 \%$ & $14.2 \%$ & $11.6 \%$ & $15.6 \%$ & $12.8 \%$ & $9.9 \%$ & $10.9 \%$ & $10.1 \%$ & $10.6 \%$ & $11.3 \%$ & $11.3 \%$ \\
ER & $42.4 \%$ & $43.5 \%$ & $48.9 \%$ & $48.0 \%$ & $49.1 \%$ & $50.3 \%$ & $52.2 \%$ & $55.7 \%$ & $53.7 \%$ & $56.4 \%$ & $54.7 \%$ & $55.4 \%$ \\
\hline
\end{tabular}

${ }^{1}$ Indicator values' background is scaled from best (green) to worst (red).

${ }^{2} \mathrm{ATR}=$ asset turnover ratio; $\mathrm{CZ}=\mathrm{Czech}$ Republic; $\mathrm{ER}=$ equity ratio; $\mathrm{FL}=$ financial leverage; $\mathrm{ROE}=$ return on equity; $\mathrm{ROS}=$ return on sales.

Table 18. Results of INFA analysis for the best company in the food industry CZ return on equity decomposition. ${ }^{1,2}$

\begin{tabular}{lcccccccccccc}
\hline & $\mathbf{2 0 0 7}$ & $\mathbf{2 0 0 8}$ & $\mathbf{2 0 0 9}$ & $\mathbf{2 0 1 0}$ & $\mathbf{2 0 1 1}$ & $\mathbf{2 0 1 2}$ & $\mathbf{2 0 1 3}$ & $\mathbf{2 0 1 4}$ & $\mathbf{2 0 1 5}$ & $\mathbf{2 0 1 6}$ & $\mathbf{2 0 1 7}$ & $\mathbf{2 0 1 8}$ \\
\hline ROS & $7.4 \%$ & $7.8 \%$ & $9.5 \%$ & $7.5 \%$ & $8.9 \%$ & $7.7 \%$ & $7.6 \%$ & $7.7 \%$ & $6.8 \%$ & $6.6 \%$ & $7.2 \%$ & $7.8 \%$ \\
ATR & 1.68 & 1.98 & 1.92 & 1.83 & 1.77 & 1.78 & 1.60 & 1.49 & 1.86 & 1.61 & 1.7 & 1.66 \\
FL & 1.89 & 2.15 & 2.10 & 1.95 & 1.93 & 1.78 & 1.70 & 1.64 & 1.79 & 1.54 & 1.54 & 1.82 \\
ROE & $23.5 \%$ & $33.4 \%$ & $38.5 \%$ & $26.9 \%$ & $30.3 \%$ & $24.5 \%$ & $20.6 \%$ & $18.8 \%$ & $22.7 \%$ & $16.4 \%$ & $18.8 \%$ & $23.5 \%$ \\
ER & $53.0 \%$ & $46.6 \%$ & $47.5 \%$ & $51.4 \%$ & $51.9 \%$ & $56.2 \%$ & $59.0 \%$ & $60.9 \%$ & $56.0 \%$ & $65.0 \%$ & $64.9 \%$ & $54.9 \%$ \\
\hline
\end{tabular}

${ }^{1}$ Indicator values' background is scaled from best (green) to worst (red).

${ }^{2} \mathrm{ATR}=$ asset turnover ratio; $\mathrm{CZ}=\mathrm{Czech}$ Republic; $\mathrm{ER}=$ equity ratio; $\mathrm{FL}=$ financial leverage; $\mathrm{ROE}=$ return on equity; $\mathrm{ROS}=$ return on sales.

\section{Conclusions}

This research shows the appropriateness of IN models compared to other widely used models for companies operating in post-communist countries. The bankruptcy and creditworthiness models were used as pattern recognition devices of financial distress, a term used in (Agarwal and Taffler, 2007), explaining developments on individual companies' level by discussing the accounting indicators and INFA results.

Although all companies faced many issues during 2007-2018, they evaded bankruptcy. The results showed that the companies generated EVA during times when they possibly struggled to survive.

The models chosen were used in forms that work independently of the market value indicator, which was difficult to quantify given the economic conditions of the Czech Republic and other post-communist countries. This situation resulted in the low explanatory power of capital market data, especially for companies with securities of very low liquidity levels.

Hence, to analyze the competitiveness of Kazakhstan companies in the confectionery industry, the study used the Altman z-score, the Taffler z-score, IN99, IN01, IN05, and creditworthiness models and an EVA analysis, characterized by the online INFA system. The Altman z-score is derived from a likelihood test of creditstrength bankruptcy. The Taffler z-score model is a bankruptcy prediction model similar to the Altman z-score model. The IN models are a group of bankruptcy tests developed using data collated since the 1990s from thousands of Czech companies. The creditworthiness model is based on a simplified multivariate discriminant analysis for assessing the financial strength of a company. The EVA analysis and its decomposion identifies the profits that remain after the capital costs of a company (both debt and equity) are deducted from the operating profit. This ensures true profit which accounts for the cost of capital including opportunity costs. 
All models used different ratios, accounting variables, and thresholds to analyze a company's financial strength and performance. Although the models used are similar, the comparison of results is not straightforward because each model defines a slightly different interpretation of results. Each model assigned a state to the company. The development of accounting indicators of the analyzed companies were discussed in order to explain possible causes leading to assigned states.

Having experienced management, fully aware of local market specifics, is important. The market in Kazakhstan is influenced by continual changes in politics and economics, and company executives need to adapt quickly. Specifics of the whole market include high-interest rates causing fluctuation and hard predictability of interest expenses for all indebted companies. The depreciation of RUB and KZT currencies linked to crude oil prices that plummeted during the Great Recession creates a permanent threat because, given observed oil supply and demand trends, it is unlikely that the currencies will appreciate notably in the following years. Oil prices may also decrease slightly with the next regional recession, and companies will again face distressing conditions.

Such a business environment is not considered as standard by European terms. Possibly, for a more effective financial analysis, the managers could use a similar approach to that of the Czech Republic where the Ministry of Industry and Trade, through cooperation with the Prague University of Economics and Business, operates a web portal for every company to enter their data and receive model results and, most importantly, a comparison with the rest of the market.

The Czech approach uses a 'benchmarking diagnostic system of INFA financial indicators' (MPO, 2007). This system helps businesses verify their financial strength and compare their results with the industry's best company and averages of the best-, moderate-, and worst-performing companies, to identify the company's major advantages. This helps understand the financial situation of a company and its development. Such an analysis is the starting point for shaping and defining a business strategy. The INFA also calculates EVA and its decomposition to other indicators.

The INFA system calculates EVA in absolute terms. This is a crucial indicator for assessing the company's long-term competitiveness. Financial analysts find that the cost of owner's equity is constantly challenging to calculate, whereas the INFA system solves this problem. This system considers and quantifies a range of risks reflected as the risk premium for financial structure, financial stability, business risk, size of the company, and liquidity. It also considers the effect of return on sales, turnover, and leverage because decomposition of the factors influencing the profitability of equity is possible.

Evaluation of the presented results from various models is not straightforward, as each model is slightly different even within the same family of models (e.g. bankruptcy, creditworthiness, mixed, or other). Thus, it is difficult to determine which model performed the best, or worst. Some presented models assign a higher priority to liquidity than to rentability, some point to the higher probability of economic profit creation. The company can have large profits or generate EVA, yet be near bankruptcy because the company ignores indicators of adequate indebtedness and liquidity and instead focuses on top performance. Such a company position would be similar to a marathon runner who, powered by various aids (in a company's context, this could be debt), wins a world record but then collapses past the target tape and is unable to race again.

The findings show that using a single model to analyze competitiveness is insufficient and that other models can provide additional useful information. Each model uses slightly different ratios, which is necessary to take into account when interpreting results. Developing a country-specific model(s) is recommended, as using models constructed from companies' data from a different country may be potentially problematic. The INFA model provided several effective variables and some interesting insights. Research results show that the IN models and the INFA indicator system effectively analyze companies' financial performance from other post-communist countries, including Kazakhstan. Based on the results, it is recommended that the Kazakh authorities develop a system similar to the INFA model and provide it to local companies free of charge for comparion and analysis of their competitiveness within the local market, as does the Czech Republic. 


\section{Supplementary material}

Supplementary material can be found online at https://doi.org/10.22434/IFAMR2020.0206

Appendix A. Translation table (Russian - Czech - English - Ukrainian)

Appendix B. Decomposition of economic value added

Table S1. ROE (\%).

Table S2. $\mathrm{r}_{\mathrm{e}}(\%)$

Table S3. Spread $\left(\mathrm{ROE}-\mathrm{r}_{\mathrm{e}}\right)(\%)$.

Table S4. Owner's equity (USD millions).

Appendix C. Comparison of ROE, ATR, and FL across analyzed companies

Table S5. Return on sales.

Table S6. Asset turnover ratio.

Table S7. Financial leverage.

\section{Conflict of interests}

The authors declare no conflict of interest.

\section{References}

Agarwal, V. and R.J. Taffler. 2007. Twenty-five years of the Taffler z-score model: does it really have predictive ability? Accounting and Business Research 37(4): 285-300. https://doi.org/10.1080/000 14788.2007.9663313

Alimbekova, G., A. Baidildina and U. Dzhakisheva. 2017. Ways of financial recovery and prevent bankruptcy. Journal of Engineering and Applied Sciences 12(3): 653-659.

Altman, E.I. 1968. Financial ratios, discriminant analysis and the prediction of corporate bankruptcy. The Journal of Finance 23: 589-609. https://doi.org/10.1111/j.1540-6261.1968.tb00843.x

Atlantis. 2017. Used bankruptcy and creditworthy models. Available at: http://www.finanalysis.cz/pouzitebankrotni-modely.html

Bayan Sulu. 2013. Bayan Sulu 2013 annual report. Kazakhstan Stock Exchange (KASE). Available at: https://kase.kz/files/emitters/BSUL/bsulp_2013_rus.pdf

Bayan Sulu. 2014. Bayan Sulu 2014 annual report. Kazakhstan Stock Exchange (KASE). Available at: https://kase.kz/files/emitters/BSUL/bsulp_2014_rus.pdf

Bayan Sulu. 2015. Bayan Sulu 2015 annual report. Kazakhstan Stock Exchange (KASE). Available at: https://kase.kz/files/emitters/BSUL/bsulp_2015_rus.pdf

Bayan Sulu. 2016. Bayan Sulu 2016 annual report. Kazakhstan Stock Exchange (KASE). Available at: https://kase.kz/files/emitters/BSUL/bsulp_2016_rus.pdf

Bayan Sulu. 2017. Bayan Sulu 2017 annual report. Kazakhstan Stock Exchange (KASE). Available at: https://kase.kz/files/emitters/BSUL/bsulp_2017_rus.pdf

Bayan Sulu. 2018. Bayan Sulu 2018 annual report. Kazakhstan Stock Exchange (KASE). Available at: https://kase.kz/files/emitters/BSUL/bsulp_2015_rus.pdf

Bayan Sulu. 2020. Bayan Sulu reporting. Available at: https://kase.kz/ru/issuers/BSUL/y0g3

BВC. 2014. Фабрика украинских конфет “Рошен” в Липецке закрыта. March 20. Available at: http:// www.bbc.com/russian/international/2014/03/140320_roschen_lipetsk_troubles

Bezkorovaynaya, K. 2018. Karaganda confectionery factory will produce innovated products. Available at: http://ekaraganda.kz/?mod=news_read\&id=72957

Bureau of National Statistics of the Agency for Strategic Planning and Reforms of the Republic of Kazakhstan (MNERK). 2020. Statisics of prices: on inflation in the republic of Kazakhstan. MNERK, Nur-Sultan, Republic of Kazakhstan. Available at: https://stat.gov.kz/official/industry/26/statistic/6 
CHRIS-ICE CC1. 2020. Historical futures prices: cocoa futures, continuous contract \#1. non-adjusted price based on spot-month continuous contract calculations. Raw data from ICE. June 17. Available at: https://www.quandl.com/data/CHRIS/ICE_CC1-Cocoa-Futures-Continuous-Contract-1-CC1-FrontMonth

CHRIS-ICE SB1. 2020. Historical futures prices: sugar no. 11 futures, continuous contract \#1. non-adjusted price based on spot-month continuous contract calculations. Raw data from ICE. June 17. Available at: https://www.quandl.com/data/CHRIS/ICE_SB1-Sugar-No-11-Futures-Continuous-Contract

CHRIS-LIFFE W5. 2020. Historical futures prices: white sugar future, continuous contract \#5. non-adjusted price based on spot-month continuous contract calculations. Raw data from LIFFE. June 17. Available at: https://www.quandl.com/data/CHRIS/LIFFE_W5-White-Sugar-Future-Continuous-Contract-5-W5

CNB. 2018. Central bank exchange rate fixing. Available at: https:/www.cnb.cz/cs/financni-trhy/devizovytrh/kurzy-devizoveho-trhu/kurzy-devizoveho-trhu/rok_form.html

Credit Guru Inc. 2018. The Altman Z-score for private firms. Available at: http://www.creditguru.com/index. php/bankruptcy-and-insolvency/altman-z-score-insolvency-predictor-for-private-firms

CRF. 2017. Ratios and formulas in customer financial analysis. Available at: https://www.crfonline.org/ orc/cro/cro-16.html

Dergunova, I. 2019. Spasite Karagandinskuyu konditerskuyu fabriku [Save the Karaganda Confectionery]. Gazeta. Available at: https://nv.kz/2019/12/13/240093/

Euromonitor. 2016. Confectionery in Kazakhstan. Executive summary of country report. Available at: http:// www.euromonitor.com/confectionery-in-kazakhstan/report

Focus. 2010. Roshen will build another confectionary factory in Russia [Roshen postroit yeshche odnu konditerskuyu fabriku v Rossii]. Available at: https:/focus.ua/money/145303/

Ginsburg, V. 2017. V Kazakhstane za 9 mesyatsev proizvodstvo konditerskikh izdeliy uvelichilos'na 17\% [In Kazakhstan during 9 months the production of confectionery products increased by 17\%]. Available at: https://agrosektor.kz/agriculture-news/v-kazahstane-za-9-mesyacev-proizvodstvo-konditerskihizdelij-uvelichilos-na-17.html

Grünwald, R. and J. Holečková. 2007. Finanční analýza a plánování podniku [Financial analysis and business planning]. Ekopress, Prague, Czech Republic.

International Massmedia Agency (IMM). 2017. Roshen is selling the factory in Mariupol. Available at: https://intmassmedia.com/2017/03/22/roshen-is-selling-the-factory-in-mariupol/

International Monetary Fund (IMF). 2020a. Exchange rates selected indicators for Ukraine: domestic currency per U.S. Dollar, end of period. Available at: https://data.imf.org/regular.aspx?key=61545850

International Monetary Fund (IMF). 2020b. International financial statistics. Available at: https://data.imf. org/?sk=85b51b5a-b74f-473a-be16-49f1786949b3

Janshanlo, R.E., M.E. Noyanov and G.T. Andybayeva. 2016. Simulation of company's bankruptcy probability based on catastrophe theory. Indian Journal of Science and Technology 9(47): 1-12. https://doi. org/10.17485/ijst/2016/v9i47/104992

KDV - Yaskino reporting. 2020. KDV - Yaskino documents. Available at: http:/www.list-org.com/ company $/ 9040$

Kislingerová, E. 2010. Manažerské finance [Managerial Finance]. C.H. Beck, Prague, Czech Republic.

Kislingerová, E. and J. Hnilica. 2008. Finančni analýza: krok za krokem [Financial analysis step by step]. C.H. Beck, Prague, Czech Republic.

Konti JSC. 2020. Reporting of JSC 'KONTI. Available at: https://konti.ua/en/for-issuer

Konti reporting. 2020. Konti documents. Available at: http://www.list-org.com/company/5787

Kralicek, P., F. Böhmdorfer and G. Kralicek. 2001. Kennzahlen für Geschaftsführer [Key figures for managing directors]. Ueberreuter, Vienna, Austria.

Kršák, B., C. Sidor, L. Štrba, M. Molokáč, L. Hvizdák, P. Blištan, E. Liptkáová, R. Delina and P. Mesároš. 2015. Maximaizing the potential of mining tourism through knowledge infrastructures. Acta Montanistica Slovaca 20(4): 319-325. https://doi.org/10.3390/ams20040319 
Kursiv.kz. 2017. Kazakhstanskaya konditerskaya produktsiya zanimayet lish'49\% na rynke RK [Confectioners: 'Kazakhstan confectionery products occupy only 49\% of the market of Kazakhstan']. Available at: https://kursiv.kz/news/otraslevye-temy/2017-08/konditery-kazakhstanskaya-konditerskayaprodukciya-zanimaet-lish-49-na

Machek, O. 2014. Long-term predictive ability of bankruptcy models in the Czech Republic: evidence from 2007-2012. Central European Business Review 3(2): 13-17. https://doi.org/10.18267/j.cebr.80

Maditinos, D.I., Ž. Šević and N.G. Theriou. 2006. Economic Value Added (EVA®). Is it really the best performance measure? A review of the theoretical and empirical literature. The case of Athens Stock Exchange (ASE). Technological Educational Institute of Kavala, Kavala, Greece. Available at: http:// abd.teikav.edu.gr/articles_th/EVA.pdf

Mařík, M.,and P. Maříková. 2005. Moderni metody hodnoceni výkonnosti a oceňováni podniku. [Modern methods of enterprise performance evaluation and valuation.]. Ekopress, Prague, Czech Republic.

McClure, B. 2019. All about EVA. Available at: https://www.investopedia.com/articles/fundamental/03/031203. asp

MPO. 2007. Bechmarking diagnostic system of INFA financial indicators. Available at: https://www.mpo.cz/ cz/rozcestnik/analyticke-materialy-a-statistiky/benchmarkingovy-diagnosticky-system-financnichindikatoru-infa--30195/

Ministry of Industry and Trade of the Czech Republic (MPO). 2017. Benchmarkingový diagnostický systém finančnich indikátorů INFA [klasifikace CZ-NACE] [Benchmarking diagnostic system of financial indicators INFA [CZ-NACE classification]]. Available at: https://www.mpo.cz/benchmarking/ infa-v2.html

Ministry of Industry and Trade of the Czech Republic (MPO). 2018. Benchmarkingový diagnostický systém finančnich indikátorů INFA [klasifikace CZ-NACE] [Benchmarking Diagnostic System of Financial Indicators INFA [CZ-NACE classification]]. Available at: https://www.mpo.cz/benchmarking/ infa-v2.html

National Bank of Kazakhstan (NBK). 2018. Daily official (market) foreign exchange rates. Available at: http://www.nationalbank.kz/?docid=362\&switch=english

National Bank of Kazakhstan (NBK). 2020. USDKZT daily exchange rate. Available at: http://www. nationalbank.kz/?furl=cursFull\&switch=eng

Nenadál, J., D. Vykydal and P. Halfarová. 2011. Benchmarking - mýty a skutečnost [Benchmarking - myths and reality]. Management Press, Prague, Czech Republic.

Nestlé Česko. 2020. Annual reports 2007-2018. Available at: https://or.justice.cz/ias/ui/vypis-slfirma?subjektId=446395

Neumaier, I. 2012. INFA methodology. Ministry of Industry and Trade. Available at: https://www.mpo.cz/ assets/cz/rozcestnik/analyticke-materialy-a-statistiky/2016/11/metodika-vypoctu.pdf

Neumaier, I. and I. Neumaierová. 2002. Výkonnost a tržni hodnota firmy [Performance and market value of the company]. Grada Publishing, Prague, Czech Republic.

Neumaierová, I. and I. Neumaier. 2005. Index IN05. Proceedings of the International Scientific Conference 'European Financial Systems' [Sbornik přispěvků z mezinárodni vědecké konference 'Evropské finančni systémy’]. Masaryk University, Brno, Czech Republic, pp. 143-148.

Neumaierová, I. and I. Neumaier. 2008. Proč se ujal index IN a nikoli pyramidový systém ukazatelů INFA. Ekonomika a management. Available at: https://www.vse.cz/eam/download. php?lang=en\&jnl=eam\&pdf=51.pdf

Nieburg, O. 2013. Lotte's Rakhat acquisition part of well-mapped strategic plan, says Mintel. Confectionary News. Available at: https:/www.confectionerynews.com/Article/2013/09/12/Lotte-Rakhat-acquisitionand-expansion-plans

Organisation for Economic Cooperation and Development (OECD). 2020. Russia GDP growth rate. Available at: https://radingeconomics.com/russia/gdp-growth

Pavelková, D. and A. Knápková. 2005. Výkonnost podniku z pohledu finančního manažera. [Business performance from the point of view of a financial manager]. Linde, Prague, Czech Republic.

Rakhat. 2016. JSC Rakhat 2016 annual report. Kazakhstan Stock Exchange (KASE). Available at: http:// www.kase.kz/files/emitters/RAHT/rahtp_2016_rus.pdf 
Rakhat. 2017. JSC Rakhat 2017 annual report. Kazakhstan Stock Exchange (KASE). Available at: https:// kase.kz/files/emitters/RAHT/rahtp_2017_rus.pdf

Rakhat. 2018. JSC Rakhat 2018 annual report. Kazakhstan Stock Exchange (KASE). Available at: https:// kase.kz/files/emitters/RAHT/rahtp_2018 rus.pdf

Rakhat. 2020. Rakhat reporting documents. Kazakhstan Stock Exchange (KASE). Available at: https://kase. $\mathrm{kz} / \mathrm{ru} /$ issuers/RAHT/y0g3

Republic of Kazakhstan (KZ). 2007. KZ Law 234/III on accounting and financial reporting. Available at: https://online.zakon.kz/Document/?doc_id=30092011

Roshen. 2014. The 2013 balance sheet. Available at: http://www.list-org.com/company/584976

Roshen. 2020. Vysnovky reviziynoyi komisiyi [Conclusions of the audit commission] 2013-2018. June 28. Available at: http://kcf.roshen.com/

Růčková, P. 2011. Finanční analýza: metody, ukazatele, využití v praxi [Financial analysis: methods, indicators, use in practice]. Grada Publishing, Prague, Czech Republic.

Škodáková, P. 2009. Návrh modelu pro měření a řizení výkonnosti podniků s využitím benchmarkingu v podminkách klastrů [Proposed Model for Measuring and Managing Company Performance by Benchmarking under Cluster Conditions]. PhD doctoral thesis, Tomas Bata University, Zlín, Czech Republic. Available at: https://tinyurl.com/skodakova2009

Stewart, G.B. 1991. The quest for value: the EVA management guide. HarperBusiness, New York, NY, USA. Tengrinews.kz. 2017. Konditerskaya produktsiya podorozhala v Kazakhstane [Confectionery products in Kazakhstan became more expensive]. November 9. Available at: https://tengrinews.kz/kazakhstan news/konditerskaya-produktsiya-podorojala-v-kazahstane-330594/

Ukrainian Exchange (UX). 2013. From the list of the Ukrainian Stock Exchange are excluded shares PJSC 'Kiev confectionery factory 'Roshen'. Available at: http://www.ux.ua/a5239

Vochozka, M. 2011. Metody komplexniho hodnoceni podniku [Methods of comprehensive enterprise evaluation]. Grada Publishing, Prague, Czech Republic.

World Bank. 2020. World development indicators. World Bank, Washington, DC, USA. Available at: https:// data.worldbank.org/country/kazakhstan 
